In cooperation with the

Houlton Band of Maliseet Indians

\title{
Nutrients, Organic Compounds, and Mercury in the Meduxnekeag River Watershed, Maine, 2003
}

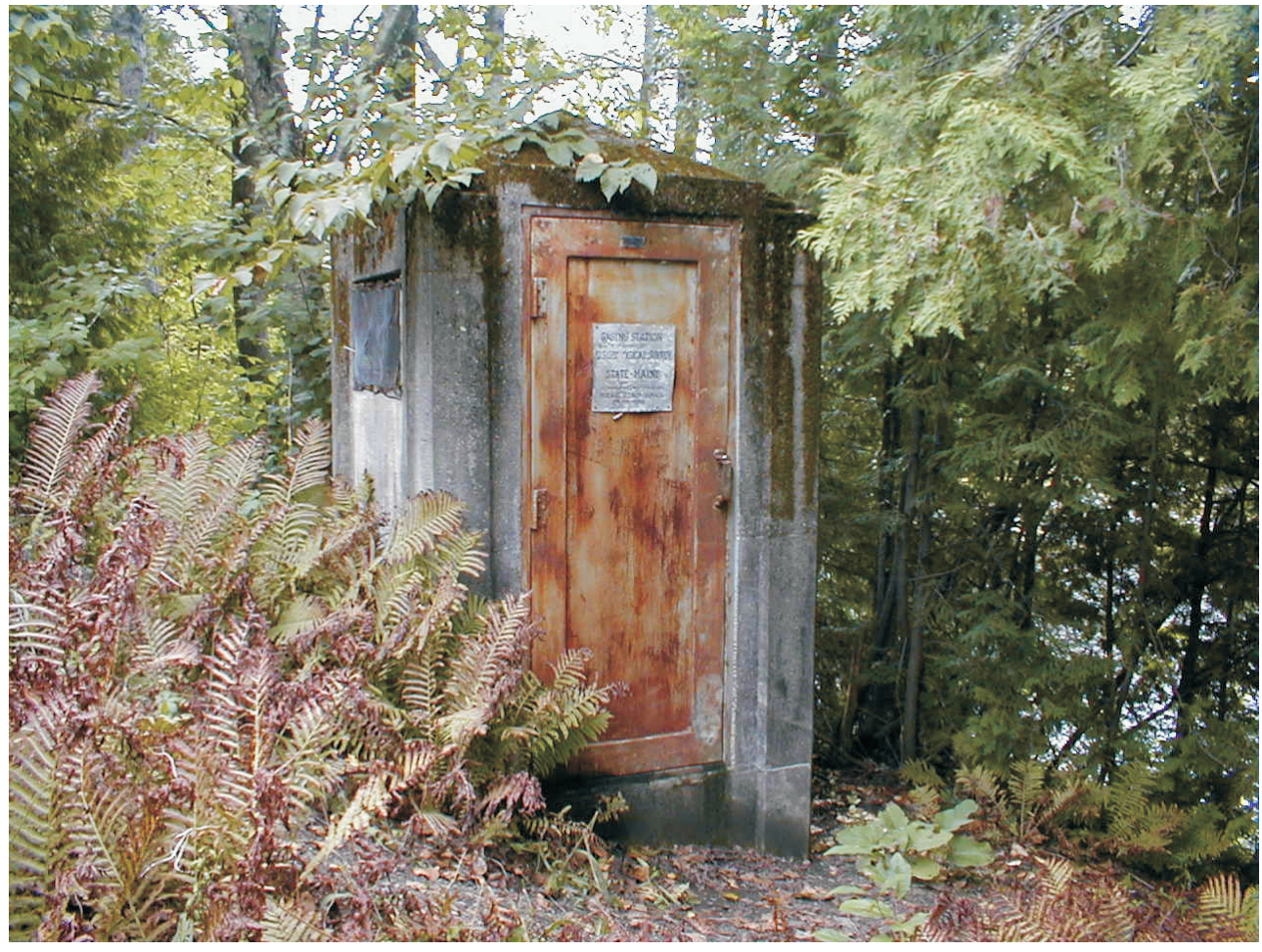

Scientific Investigations Report 2005-5111 
Cover Photograph:Streamflow gage at Meduxnekeag River near Houlton, Maine (01018000) September 2004. Photo taken by U.S. Geological Survey Maine Water Science Center staff. 


\section{Nutrients, Organic Compounds, and Mercury in the Meduxnekeag River Watershed, Maine, 2003}

By Charles W. Schalk and Lan Tornes

In cooperation with the

Houlton Band of Maliseet Indians

Scientific Investigations Report 2005-5111

U.S. Department of the Interior

U.S. Geological Survey 


\title{
U.S. Department of the Interior Gale A. Norton, Secretary
}

\author{
U.S. Geological Survey \\ Charles G. Groat, Director
}

U.S. Geological Survey, Reston, Virginia: 2005

For sale by U.S. Geological Survey, Information Services

Box 25286, Denver Federal Center

Denver, CO 80225

For more information about the USGS and its products:

Telephone: 1-888-ASK-USGS

World Wide Web: http://www.usgs.gov/

Any use of trade, product, or firm names in this publication is for descriptive purposes only and does not imply endorsement by the U.S. Government.

Although this report is in the public domain, permission must be secured from the individual copyright owners to reproduce any copyrighted materials contained within this report. 


\section{CONTENTS}

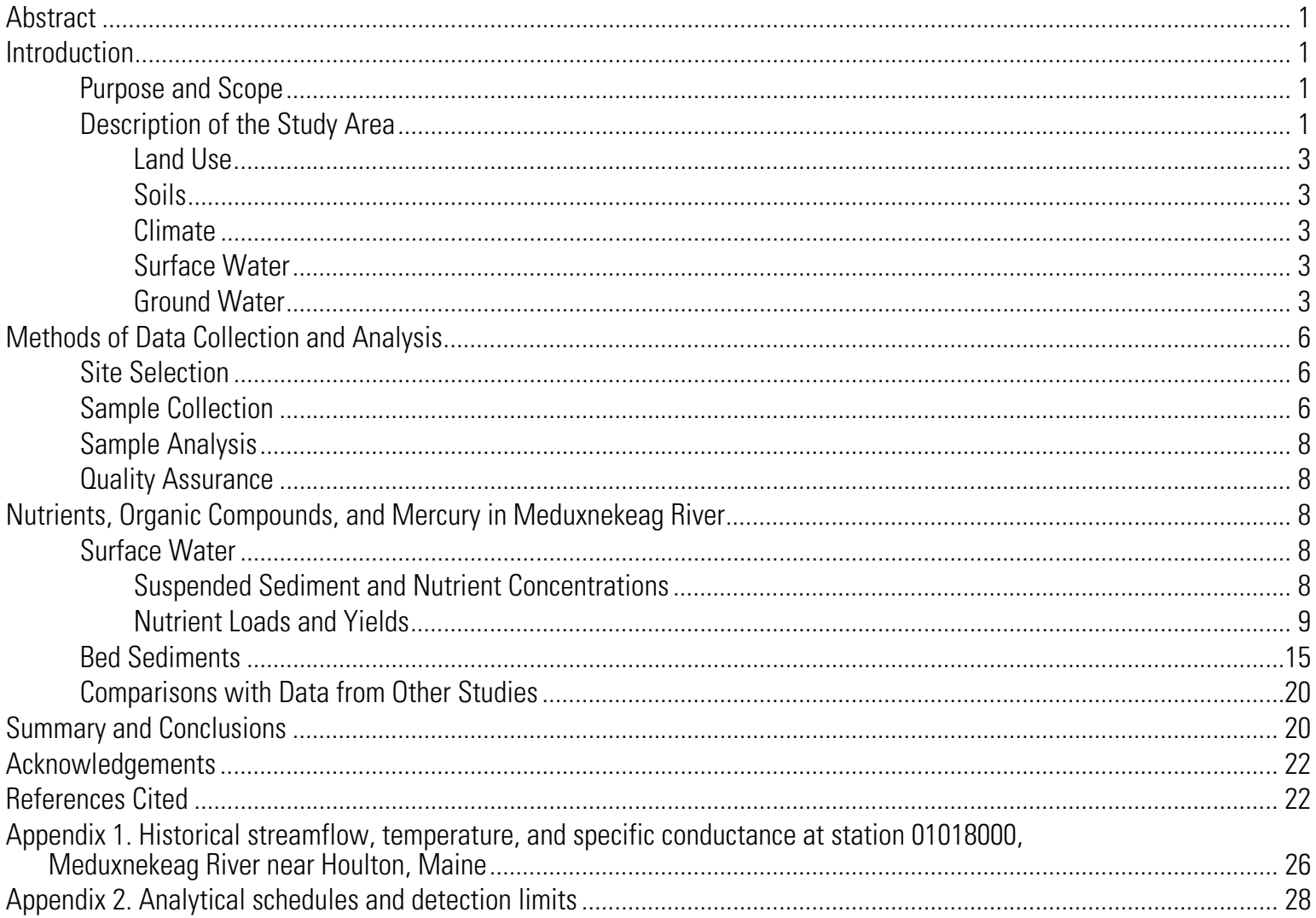

\section{Figures}

1-2. Maps showing:

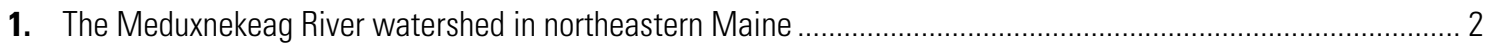

2. Locations of sampling stations in the Meduxnekeag River watershed, Maine ................................................ 4

3-5. Graphs showing:

3. Mean daily flow at station 01018000, Meduxnekeag River near Houlton, Maine ............................................. 5

4. Mean and maximum monthly flows at station 01018000, Meduxnekeag River near Houlton, Maine .................... 5

5. Median concentrations of nitrogen (N) in surface-water samples from Meduxnekeag River

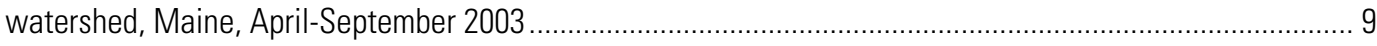

6. Map showing:

6. Streamflow and nitrogen (N) loads, Meduxnekeag River subwatershed, Maine, June 2-3, 2003

7-8. Graphs showing:

7. Concentrations of carbon and mercury at stations on Meduxnekeag River, Maine, July 2003. 16

8. Sum of concentrations of polycyclic aromatic hydrocarbons in bed-sediment samples from Meduxnekeag River, Maine, July 2003. 


\section{Tables}

1. Characteristics of sampling locations, Meduxnekeag River watershed, Maine .................................................. 6

2. Dates and locations of samples collected in Meduxnekeag River watershed, Maine, 2003 ................................ 7

3. Concentrations of suspended sediment at selected stations, Meduxnekeag River watershed

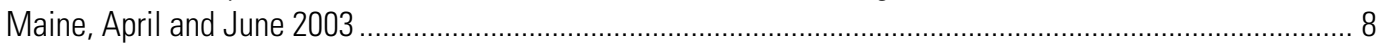

4. Concentrations of selected nutrients in surface water, Meduxnekeag River watershed

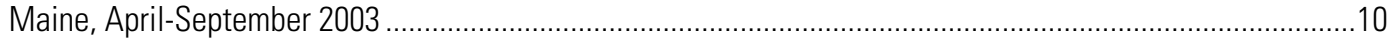

5. Concentrations of selected nutrients in quality-assurance samples, Meduxnekeag River watershed Maine, April-July 2003

6. Streamflow and physical properties, Meduxnekeag River watershed, Maine, April-September 2003

7. Concentrations of phosphorus in bed sediment, Meduxnekeag River watershed Maine, July 2003

8. Instantaneous nitrogen loads and yields at selected stations in Meduxnekeag River watershed, Maine, April and June 2003 13

9. Bed-sediment particle-size distributions, Meduxnekeag River, Maine, July 2003

10. Concentrations of mercury, carbon, and hydrophobic organic compounds in bed sediment,

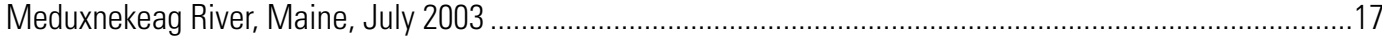

11. Range of suspended-sediment concentrations in samples from three New England rivers, 1998-2003 ................20

12. Summary of nutrient concentrations in samples from Stillwater River, Massachusetts, and Kennebec and Meduxnekeag Rivers, Maine, 1998-2003

\section{Conversion Factors}

\begin{tabular}{lll}
\hline Multiply & By & To obtain \\
\hline inch (in.) & 2.54 & centimeter $(\mathrm{cm})$ \\
foot (ft) & 0.3048 & meter $(\mathrm{m})$ \\
square mile $\left(\mathrm{mi}^{2}\right)$ & 2.590 & square kilometer $\left(\mathrm{km}^{2}\right)$ \\
gallons per day $(\mathrm{gal} / \mathrm{d})$ & 3.785 & liter per day $(\mathrm{L} / \mathrm{d})$ \\
cubic foot per second $\left(\mathrm{ft}^{3} / \mathrm{s}\right)$ & 0.02832 & cubic meter per second $\left(\mathrm{m}^{3} / \mathrm{s}\right)$ \\
\hline
\end{tabular}

Water-quality units. Concentrations of constituents in aqueous solution are reported in units of milligrams per liter (mg/L). Concentrations of constituents in soil are reported in units of micrograms per gram $(\mu \mathrm{g} / \mathrm{g})$, milligrams per kilogram $(\mathrm{mg} / \mathrm{kg})$, or micrograms per kilogram $(\mu \mathrm{g} / \mathrm{kg})$. Concentrations can be multiplied by flow rate to obtain units of kilograms per day $(\mathrm{kg} / \mathrm{d})$.

Temperature in degrees Celsius $\left({ }^{\circ} \mathrm{C}\right)$ may be converted to degrees Fahrenheit $\left({ }^{\circ} \mathrm{F}\right)$ as follows:

$$
{ }^{\circ} \mathrm{F}=1.8\left({ }^{\circ} \mathrm{C}\right)+32
$$




\title{
Nutrients, Organic Compounds, and Mercury in the Meduxnekeag River Watershed, Maine, 2003
}

\author{
By Charles W. Schalk and Lan Tornes
}

\section{Abstract}

In 2003, the U.S. Geological Survey, in cooperation with the Houlton Band of Maliseet Indians, sampled streambed sediments and surface water of the Meduxnekeag River watershed in northeastern Maine under various hydrologic conditions for nutrients, hydrophobic organic compounds, and mercury. Nutrients were sampled to address concerns related to summer algal blooms, and organic compounds and mercury were sampled to address concerns about regional depositional patterns and overall watershed quality. In most surface-water samples, phosphorus was not detected or was detected at concentrations below the minimum reporting limit. Nitrate and organic nitrogen were detected in every surface-water sample for which they were analyzed; the highest concentration of total nitrogen was 0.75 milligrams per liter during low flow. Instantaneous nitrogen loads and yields were calculated at four stations for two sampling events. These data indicate that the part of the watershed that includes Houlton, its wastewater-treatment plant, and four small urban brooks may have contributed high concentrations of nitrate to Meduxnekeag River during the high flows on April 23-24 and high concentrations of both organic and nitrate nitrogen on June 2-3. Mercury was detected in all three bed-sediment samples for which it was analyzed; concentrations were similar to those reported from regional studies. Notable organic compounds detected in bed sediments included $\mathrm{p}, \mathrm{p}^{\prime}-$ DDE and p,p'-DDT (pesticides of the DDT family) and several polycyclic aromatic hydrocarbons. Polychlorinated biphenyls (PCBs) and phthalates were not detected in any sample, whereas p-cresol was the only phenolic compound detected. Phosphorus was detected at concentrations below 700 milligrams per kilogram in each bed-sediment sample for which it was analyzed. Data were insufficient to establish whether the lack of large algal blooms in 2003 was related to low concentrations of phosphorus.

\section{Introduction}

The Houlton Band of Maliseet Indians (HBMI) lives in the Meduxnekeag River watershed near Houlton, Maine. HBMI is actively involved in land- and water-resource management programs to improve the quality of water in the Meduxnekeag River watershed. They have documented several seasonal problems with Meduxnekeag River and its tributaries, including high sediment loads during runoff events, occasional algal blooms, and increased concentrations of phosphorus during low flows (unpublished data on file with the HBMI). In response to these observations, HBMI and the U.S. Geological Survey (USGS) began a cooperative program to investigate the seasonal occurrence of nutrients in surface water and bed sediments of Meduxnekeag River. USGS hypothesized that nutrient-enriched sediments in the streams are the source of persistent phosphorus that feeds the algae during summer months. USGS and HBMI designed a study to investigate the relations among streamflow, water quality, and bed-sediment quality in the Meduxnekeag River watershed. Because of HBMI's concerns about regional depositional patterns and the effects of urbanization and agriculture on stream quality, mercury and hydrophobic organic compounds were included in the bed-sediment analyte list.

\section{Purpose and Scope}

This report presents surface-water and bed-sediment data and analysis from sampling efforts in the Meduxnekeag River watershed during the 2003 growing season. These data serve three purposes: (1) to establish a baseline of nutrient, organic compound, and mercury data that can be used in future studies; (2) to show the response of nutrient concentrations to changing seasons and flow conditions in 2003; and (3) to show spatial variations in bed-sediment chemistry during a single sampling event. Samples were collected from April 2003 to September 2003 to target spring runoff, summer storms, and summer low flows. Summary tables of field parameters, nutrients, organic compounds, suspended sediment, and mercury are presented, along with secondary data, including loads and yields. The data collected during this study are compared with those from a New England regional study so that they can be placed in a regional context. Because this study was conducted during a single open-water season, the results may not be representative of those that might occur during a longer study period.

\section{Description of the Study Area}

Meduxnekeag River flows through predominantly agricultural and forested areas in northeastern Maine (fig. 1) 


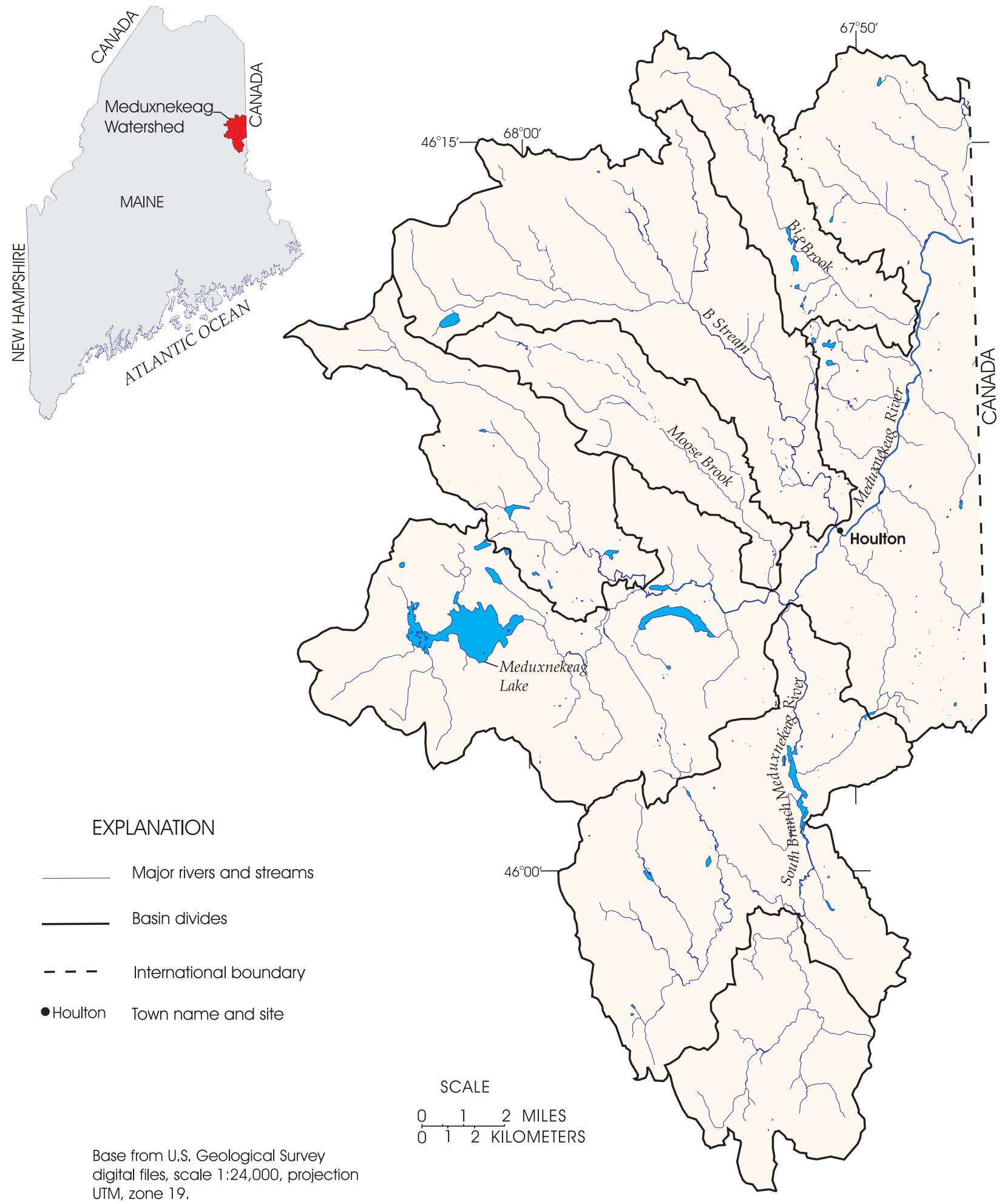

Figure 1. The Meduxnekeag River watershed in northeastern Maine. 
to its confluence with St. John River in Canada. The watershed encompasses $289 \mathrm{mi}^{2}$ (square miles) to the Canadian border. Tributaries included in the study area are South Branch Meduxnekeag River, B Stream, and smaller streams. The downstream extent of the study area is near the Maine-Canada border.

\section{Land Use}

Forests cover about 79 percent of the Meduxnekeag River watershed; agricultural lands, about 17 percent; and urban areas and open water, about 4 percent (Southern Aroostook County Soil and Water Conservation District, 1993). Primary crops include potatoes and grains. About 50 dairy and beef farms are present in the wateshed. The general trend in land use is toward gradual increases in urban and suburban areas at the expense of agricultural and forested land (Southern Aroostook County Soil and Water Conservation District, 1993).

\section{Soils}

Thickness of unconsolidated deposits in the Meduxnekeag River watershed is variable. In general, the overburden is calcareous till derived from weathered bedrock (Thompson and Borns, 1985). Much of the soil is classified as highly erodible or potentially highly erodible (U.S. Department of Agriculture, 1994). Most of the arable soils are in agricultural production and the steep, stony, and poorly drained soils are in forests. Land surface is rolling, with hills reaching an elevation of 200 to $500 \mathrm{ft}$ (feet) above valley floors.

\section{Climate}

Northeastern Maine is characterized by cold winters and short, warm summers. The growing season is 100 to 125 days. Average annual precipitation is about 39 in. (inches) (National Climatic Data Center, 1999), which includes the water equivalent from 95 in. of snow. Average temperatures range from $12^{\circ} \mathrm{F}$ in January to $68^{\circ} \mathrm{F}$ in July.

\section{Surface Water}

Although precipitation is distributed fairly evenly throughout the year, most of the annual streamflow is spring snowmelt. Snowmelt runoff has been observed to cause severe erosion in late winter and early spring (Southern Aroostook County Soil and Water Conservation District, 1993).

USGS maintains two streamflow-gaging stations in the study area (fig. 2). Station 01018000, Meduxnekeag River near Houlton, was active from 1940 to 1982, during which time rating curves were established and periodic measurements of water temperature, specific conductance, and streamflow were made (appendix 1). Station 01018000 was reactivated in 2003, in cooperation with HBMI, for additional streamflow measure- ments and water-quality monitoring. The rating curves are on file with the USGS in Augusta, Maine. Of 56 measurements of streamflow on record at station 01018000,35 are in spring months (March to May), with a median measured streamflow of $1,760 \mathrm{ft}^{3} / \mathrm{s}$ (cubic feet per second). Median measured streamflow during the rest of the year was $101 \mathrm{ft}^{3} / \mathrm{s}$. Peak recorded flow at station 01018000 was $6,010 \mathrm{ft}^{3} / \mathrm{s}$ on April 4, 1976, probably in response to snowmelt runoff. Mean daily flow at station 01018000 for the period of record, 1940-82 and 2003, is shown in figure 3 , and mean and maximum monthly flows are shown in figure 4. Station 01017960, Meduxnekeag River above South Branch, was established in 2003 to provide Maine Department of Environmental Protection with streamflow data for total maximum daily load (TMDL) calculations. Because its period of record is short, streamflow statistics are not presented.

One municipality (Houlton, population 5,270 in 2000) and one industry (A.E. Staley Manufacturing, Inc.) have permitted outfalls to Meduxnekeag River (Maine Department of Environmental Protection, 1998a, 2003). Houlton's municipal wastewater outfall is just downstream from the city limits. The A.E. Staley plant, which processes food starch (Town of Houlton, 2004), is adjacent to station 01017960 and upstream from the confluence of Meduxnekeag River with South Branch.

Most irrigation of agricultural fields is by withdrawals from Meduxnekeag River, including impoundments (Matthew Williams, University of Maine Extension, written commun., 2004). The demand for irrigation water, however, puts stress on aquatic habitat during low-flow periods (Aroostook Water and Soil Management Board, 1996).

Several organizations have documented stream-waterquality problems in Meduxnekeag River. Maine Department of Environmental Protection sampled for total phosphorus and other indicators of stream quality and identified point sources that could be contributing to impairment of the river (Maine Department of Environmental Protection, 2000). A consulting firm found that algal mats cover as much as 90 percent of the stream bottom during the summer at sites they monitored (William Ball, Acheron Engineering, Environmental \& Geologic Consultants, written commun., 2001). Fishconsumption advisories have been issued for Meduxnekeag River for elevated levels of the pesticide DDT in fish tissue (Maine Department of Environmental Protection, 2002) and for all Maine rivers because of elevated levels of mercury in fish tissue (Maine Department of Environmental Protection, 1998b).

\section{Ground Water}

The most recent regional survey of ground water is reported in Prescott (1971). Most wells surveyed by Prescott (1971) were used for domestic supplies of ground water, but other uses included commercial, industrial, and agricultural. Houlton Water Company (HWC) (2004) is the only municipal 


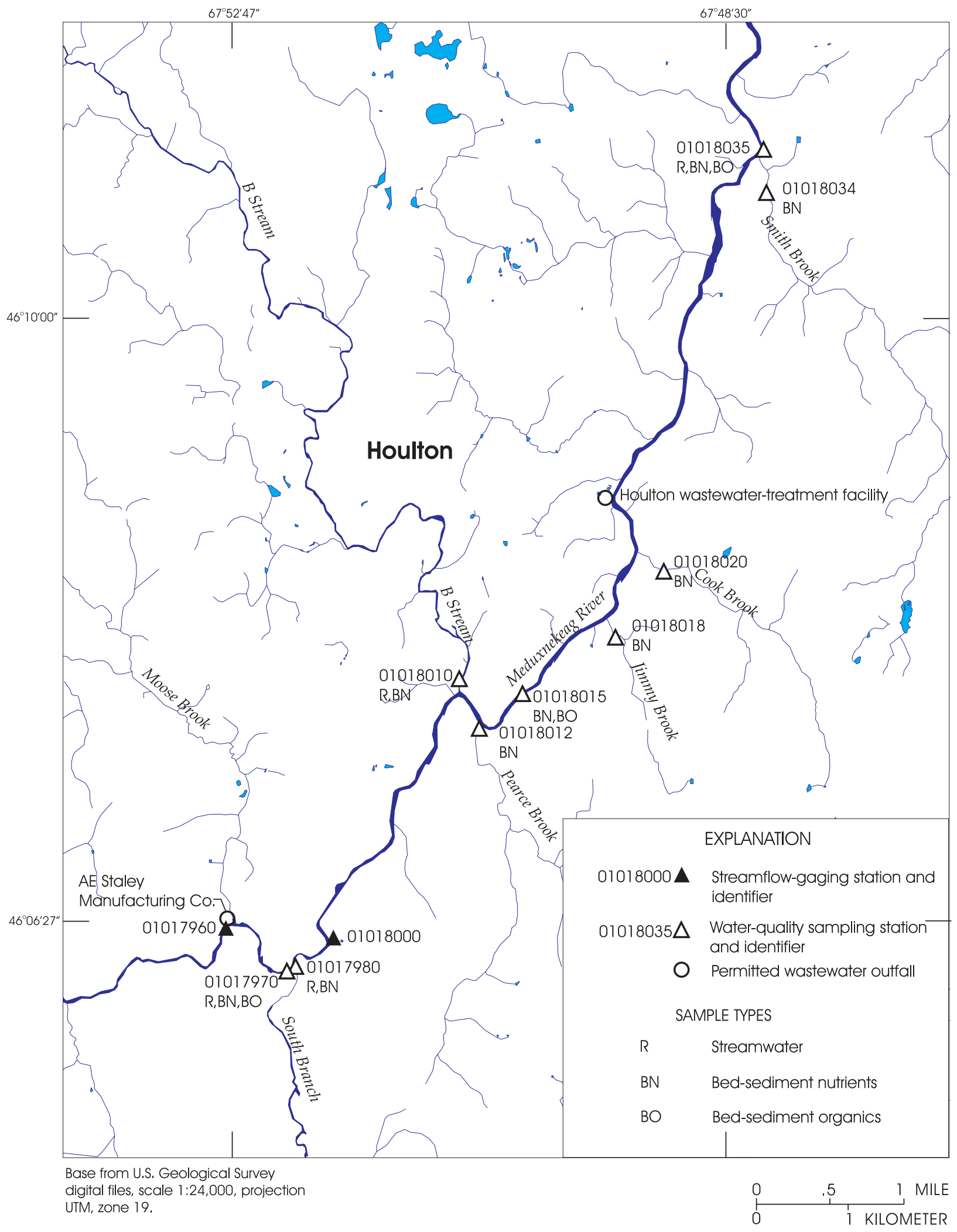

Figure 2. Locations of sampling stations in the Meduxnekeag River watershed, Maine. 


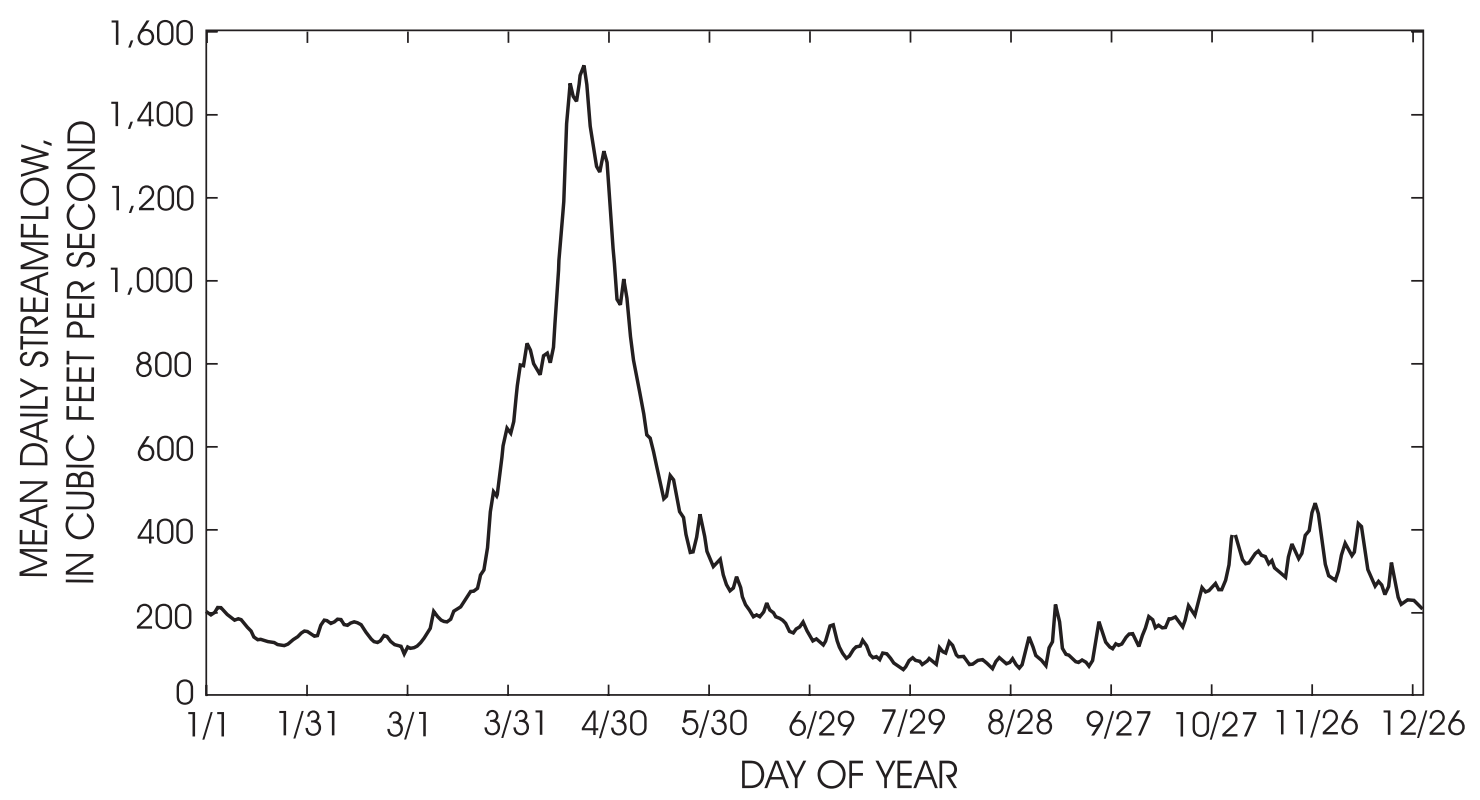

Figure 3. Mean daily flow at station 01018000, Meduxnekeag River near Houlton, Maine (period of record 1940-82 and 2003).

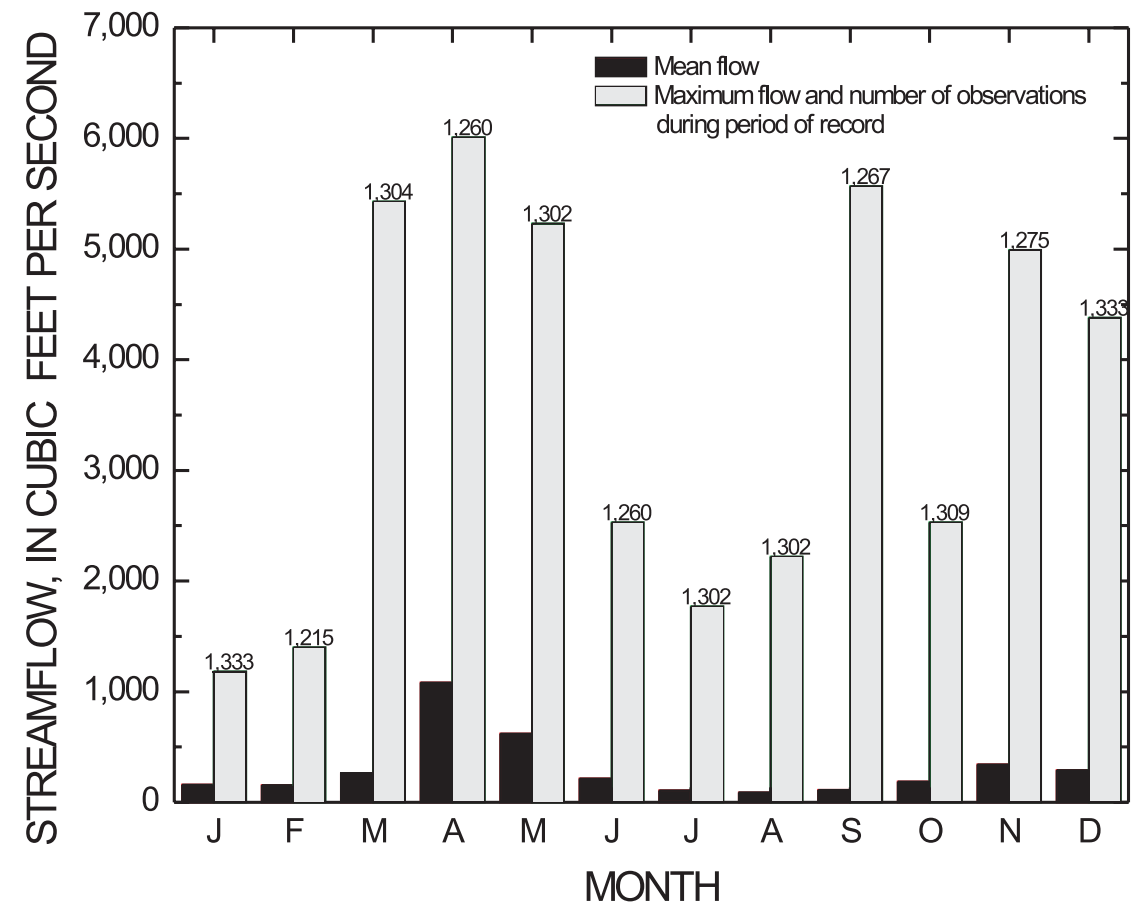

Figure 4. Mean and maximum monthly flows at station 01018000, Meduxnekeag River near Houlton, Maine (period of record 1940-82 and 2003). 
supplier of ground water in the study area, producing about $750,000 \mathrm{gal} / \mathrm{d}$ (gallons per day) from two well fields; this production is about 34 percent less than the daily volume produced in 1970 (Prescott, 1971).

\section{Methods of Data Collection and Analysis}

This study was designed primarily to assess the presence and transport of nutrients during seasonal flows and relate concentrations of nutrients to the presence of filamentous algal blooms in Meduxnekeag River during low-flow periods. To improve understanding of water quality in the Meduxnekeag River watershed, USGS collected samples for analysis of other constituents also. Suspended-sediment samples were collected at high and medium flows. Bottom sediments were collected from depositional areas along the river and tributaries during a low-flow period; these samples were analyzed for hydrophobic organic compounds, particle-size distribution, mercury, and phosphorus.

\section{Site Selection}

Five surface-water and four bed-sediment sampling stations were established for this study. Two stations01017970 and 01018035 - were established to monitor upstream and downstream concentrations in Meduxnekeag River (fig. 2 and table 1) and provide estimates of concentration gradients along the stream reach. Station 01017970 is above the confluence of South Branch and Meduxnekeag River, and station 01018035 is at Lowery Road near HBMI headquarters north of Houlton. Two major tributaries, South Branch (01017980) and B Stream (01018010), were sampled frequently for estimates of inputs from adjacent areas. Bed- sediment stations were established on smaller tributaries and station 01018015 (Meduxnekeag River at Highland Avenue); these stations were sampled to identify bed-sediment chemistry along the entire reach of the study area. Timing of sampling was designed to optimize the possibility of sampling a large range of flows and nutrient concentrations during the spring and summer months.

\section{Sample Collection}

Surface water and bed sediments were sampled during the spring and summer of 2003. Surface water was sampled in downstream order under stable flow conditions at one to four stations during eight sampling events and bed sediments were sampled at nine stations during a single 2-day event. Surfacewater sampling spanned 2 days in two events (April 23-24 and June 2-3, 2003). The earliest samples were collected in April when snowmelt runoff was high. Samples were collected four times in the spring, four times during low flows in the summer, and one time during high flow in the summer. Dates and location of samples collected are presented in table 2 .

Two protocols for sampling surface water were used. USGS used an equal-width increment method and a D-59, DH48, or D-77 sampler (U.S. Geological Survey, variously dated); samples for nutrients and suspended sediment were split into bottles by use of a polyethylene churn splitter. Members of HBMI sampled surface water by a centroid-offlow method; samples were split by decanting from the grab bucket into bottles. Samples for dissolved nutrients (see table 2D, appendix 2) were filtered through 0.45-micron disk- or capsule-type filters, preserved as required, and chilled; wholewater samples were preserved, chilled, and shipped without

Table 1. Characteristics of sampling locations, Meduxnekeag River watershed, Maine.

\begin{tabular}{lllcc}
\hline Station identifier & Station name & Latitude & $\begin{array}{c}\text { Drainage } \\
\text { area } \\
\text { Longitude } \\
\text { (square } \\
\text { miles) }\end{array}$ \\
\hline 01017970 & Meduxnekeag River at Porter Settlement Road & $46^{\circ} 06^{\prime} 07^{\prime \prime}$ & $67^{\circ} 52^{\prime} 22^{\prime \prime}$ & 106 \\
01017980 & South Branch Meduxnekeag River & $46^{\circ} 06^{\prime} 08^{\prime \prime}$ & $67^{\circ} 52^{\prime} 18^{\prime \prime}$ & 69 \\
01018010 & B Stream at Route 2, Houlton & $46^{\circ} 07^{\prime} 48^{\prime \prime}$ & $67^{\circ} 50^{\prime} 53^{\prime \prime}$ & 45 \\
01018012 & Pearce Brook at Houlton ${ }^{1}$ & $46^{\circ} 07^{\prime} 32^{\prime \prime}$ & $67^{\circ} 50^{\prime} 44^{\prime \prime}$ & 8.04 \\
01018015 & Meduxnekeag River at Highland Avenue, Houlton & $46^{\circ} 07^{\prime} 43^{\prime \prime}$ & $67^{\circ} 50^{\prime} 21^{\prime \prime}$ & 231 \\
01018018 & Jimmy Brook at Houlton ${ }^{1}$ & $46^{\circ} 08^{\prime} 08^{\prime \prime}$ & $67^{\circ} 49^{\prime} 39^{\prime \prime}$ & 0.91 \\
01018020 & Cook Brook at Houlton ${ }^{1}$ & $46^{\circ} 08^{\prime} 33^{\prime \prime}$ & $67^{\circ} 49^{\prime} 25^{\prime \prime}$ & 8.09 \\
01018034 & Smith Brook at Houlton ${ }^{1}$ & $46^{\circ} 10^{\prime} 51^{\prime \prime}$ & $67^{\circ} 48^{\prime} 22^{\prime \prime}$ & 8.01 \\
01018035 & Meduxnekeag River at Lowery Road & $46^{\circ} 10^{\prime} 52^{\prime \prime}$ & $67^{\circ} 48^{\prime} 16^{\prime \prime}$ & 257 \\
\hline
\end{tabular}

${ }^{1}$ Drainage areas were calculated at given coordinates; sampling locations differed slightly. 
Table 2. Dates and locations of samples collected in Meduxnekeag River watershed, Maine, 2003.

[USGS, U.S. Geological Survey; HBMI, Houlton Gand of Maliseet Indians].

\begin{tabular}{|c|c|c|c|c|c|}
\hline Date & Station identifier & $\begin{array}{l}\text { Sampling } \\
\text { personnel }\end{array}$ & Target analytes & Medium & Flow condition \\
\hline April 23, 2003 & $\begin{array}{l}01017970^{\mathrm{a}} \\
01017980\end{array}$ & USGS & $\begin{array}{l}\text { Field measurements } \\
\text { Suspended sediment } \\
\text { Nutrients }\end{array}$ & Surface water & $\begin{array}{l}\text { High-snowmelt } \\
\text { runoff }\end{array}$ \\
\hline April 24, 2003 & $\begin{array}{l}01018010 \\
01018035^{\mathrm{a}}\end{array}$ & USGS & $\begin{array}{l}\text { Field measurements } \\
\text { Suspended sediment } \\
\text { Nutrients }\end{array}$ & Surface water & $\begin{array}{l}\text { High-snowmelt } \\
\text { runoff }\end{array}$ \\
\hline May 30, 2003 & $\begin{array}{l}01017970 \\
01018035\end{array}$ & HBMI & $\begin{array}{l}\text { Field measurements } \\
\text { Nutrients }\end{array}$ & Surface water & Medium \\
\hline June 2, 2003 & $\begin{array}{l}01017970 \\
01017980\end{array}$ & USGS & $\begin{array}{l}\text { Field measurements } \\
\text { Suspended sediment } \\
\text { Nutrients }\end{array}$ & Surface water & Medium \\
\hline June 3, 2003 & $\begin{array}{l}01018010 \\
01018035\end{array}$ & USGS & $\begin{array}{l}\text { Field measurements } \\
\text { Suspended sediment }{ }^{b} \\
\text { Nutrients }\end{array}$ & Surface water & Medium \\
\hline June 18, 2003 & $\begin{array}{l}01017970 \\
01018010 \\
01018035\end{array}$ & HBMI & Nutrients & Surface water & Low \\
\hline July 7, 2003 & $\begin{array}{l}01017970 \\
01017980 \\
01018010 \\
01018035^{\mathrm{a}}\end{array}$ & HBMI & $\begin{array}{l}\text { Field measurements } \\
\text { Nutrients } \\
\text { Mercury } \\
\text { Carbon } \\
\text { Organic compounds }\end{array}$ & Surface water & Low \\
\hline July 16, 2003 & $\begin{array}{l}01017970 \\
01017980^{c}\end{array}$ & USGS & $\begin{array}{l}\text { Nutrients } \\
\text { Mercury } \\
\text { Carbon } \\
\text { Organic compounds }\end{array}$ & Bed sediment & Low \\
\hline July 17,2003 & $\begin{array}{l}01018010^{\mathrm{c}} \\
01018012^{\mathrm{c}} \\
01018015 \\
01018018^{\mathrm{c}} \\
01018020^{\mathrm{c}} \\
01018034^{\mathrm{c}} \\
01018035\end{array}$ & USGS & $\begin{array}{l}\text { Nutrients } \\
\text { Mercury } \\
\text { Carbon } \\
\text { Organic compounds }\end{array}$ & Bed sediment & Low \\
\hline July 24, 2003 & $\begin{array}{l}01017970 \\
01017980 \\
01018010 \\
01018035\end{array}$ & HBMI & Nutrients & Surface water & Low \\
\hline $\begin{array}{l}\text { August 6, } 2003 \\
\text { September 3, } 2003\end{array}$ & $\begin{array}{l}01018035 \\
01017970 \\
01017980 \\
01018010\end{array}$ & $\begin{array}{l}\text { HBMI } \\
\text { HBMI }\end{array}$ & $\begin{array}{l}\text { Nutrients } \\
\text { Nutrients }\end{array}$ & $\begin{array}{l}\text { Surface water } \\
\text { Surface water }\end{array}$ & $\begin{array}{l}\text { High } \\
\text { Low }\end{array}$ \\
\hline
\end{tabular}

${ }^{\mathrm{a}}$ Quality-assurance sample also collected

${ }^{\mathrm{b}}$ Station 01018010 only

cPhosphorus only

having been filtered. All samples for chemical analysis were shipped by overnight courier using established chain-of-custody protocols to the USGS National Water-Quality Laboratory (NWQL) in Lakewood, Colo. Samples of suspended sediment were shipped to the USGS Iowa District Sediment Laboratory (IDSL) for analysis.

Samples of the top $1 \mathrm{in}$. of bed sediment were collected and composited from multiple depositional zones across the stream at each site, mixed, and sieved through a 2-mm (milli- meter) stainless-steel sieve (Shelton and Capel, 1994). Backwater areas that might have represented only localized deposition were not sampled; instead, fine sediments were collected from behind small islands and (or) obstructions such as rocks. After collection and processing, sieved samples were stored in a refrigerator for a minimum of 3 days to allow the sediments to settle because the NWQL requires that each sediment sample have a minimal amount of water. The settled sediments were shipped to the NWQL as bed-sediment samples. 
Splits of the bed-sediment samples were analyzed for particlesize distribution by the IDSL.

Notes of field activities were kept during sample collection. Included in these notes were records of measured field values (water temperature, $\mathrm{pH}$, dissolved oxygen concentration, and specific conductance), instrument calibrations, sampling techniques, conditions of the stream and weather, and number of bottles collected for analysis. Field notes are on file with the USGS in Augusta, Maine.

Discharge measurements were made at most stations during the April 23-24 and June 2-3 events. Measurements were used to calculate instantaneous loads of sediment and chemical constituents. During some sampling events, streamflow was estimated by use of stage measurements and application of established streamflow ratings. Of particular interest was the South Branch station (01017980). Streamflow could not be measured at South Branch because of the presence of rapids, but flow was estimated by subtracting streamflow at the Porter Settlement Road station (01017960, just above the confluence of South Branch and Meduxnekeag River) from streamflow at gaging station 01018000 (just below confluence of South Branch and Meduxnekeag River) under the assumption that South Branch provided the difference in streamflow. Gage height was recorded at gaging station 01018000 during sampling, and streamflow was estimated from the historical rating.

\section{Sample Analysis}

Chemical analyses of the samples collected for this study were done by the USGS NWQL in Lakewood, Colo. Samples for suspended sediment and particle-size distribution were analyzed at the USGS IDSL. Bed-sediment samples were processed through a 2-mm stainless-steel mesh sieve for analysis of organic compounds and through a 0.063-mm nyloncloth sieve for analysis of total mercury. Method references and reporting limits for analytes are presented in appendix 2 .

\section{Quality Assurance}

Quality-assurance samples are designed to provide information on the bias and representativeness of samples. During this study, two types of quality-assurance samples, blanks and replicates, were collected. The blanks were collected by different organizations: USGS collected the blank on April 23 and HBMI collected the blank on July 7. Neither of the blanks contained detectable concentrations of the nutrients for which they were analyzed, indicating that sample results were not biased by equipment contamination or sampling method.

\section{Nutrients, organic compounds, and mercury in Meduxnekeag River}

Although a primary purpose of this study was to relate nutrient concentrations to the presence of algal blooms in Meduxnekeag River, no large algal mats were observed during the 2003 sample-collection period, possibly because of seasonal variations and flushing related to summer storm events. The data described in this section, therefore, will provide a baseline for future studies and are discussed in relation to various flow conditions and spatial distributions.

\section{Surface Water}

This section contains discussion about concentrations of suspended sediment and nutrients in surface water, physical properties of surface water, and estimates of nutrient loads and yields. Assumptions used in the estimates of nutrient loads and yields are described.

\section{Suspended Sediment and Nutrient Concentrations}

Concentrations of suspended sediment ranged from 7 to $18 \mathrm{mg} / \mathrm{L}$ (milligrams per liter) during April 23-24 (snowmelt runoff) and from 3.2 to $10 \mathrm{mg} / \mathrm{L}$ during June 2-3 (table 3). Suspended-sediment concentrations in samples decreased between the two events. During both sampling events, concentrations of suspended sediment were higher in samples from downstream locations than from upstream locations.

Table 3. Concentrations of suspended sediment at selected stations, Meduxnekeag River watershed, Maine, April and June 2003.

\begin{tabular}{ccc}
\hline $\begin{array}{l}\text { Station } \\
\text { identifier } \\
\text { (Figure 2) }\end{array}$ & Sample date & $\begin{array}{l}\text { Concentration, } \\
\text { in milligrams } \\
\text { per liter }\end{array}$ \\
\hline 01017970 & $4 / 23 / 2003$ & 7 \\
01017970 & $6 / 02 / 2003$ & 5.8 \\
01017980 & $4 / 23 / 2003$ & 18 \\
01017980 & $6 / 02 / 2003$ & 10 \\
01018010 & $4 / 24 / 2003$ & 9 \\
01018010 & $6 / 03 / 2003$ & 3.2 \\
01018035 & $4 / 24 / 2003$ & 11 \\
\hline
\end{tabular}

Concentrations of nitrate $\left(\mathrm{NO}_{3}\right)$ and organic nitrogen, the forms of nitrogen present in streamwater samples, ranged from 0.04 (estimated) to $0.50 \mathrm{mg} / \mathrm{L}$ and from 0.19 to 0.62 $\mathrm{mg} / \mathrm{L}$, respectively (table 4 ). No sample contained a concentration of $\mathrm{NO}_{3}$ higher than $10 \mathrm{mg} / \mathrm{L}$ as $\mathrm{NO}_{3}$, the maximum contaminant level for drinking water (U.S. Environmental 
Protection Agency, 2004). Ammonia $\left(\mathrm{NH}_{3}\right)$ and nitrite $\left(\mathrm{NO}_{2}\right)$ were not detected in any sample for which they were analyzed and, on the basis of those nondetections, probably contributed little or nothing to total nitrogen in any other sample. Organic nitrogen, primarily from anthropogenic sources but possibly also from microbial processes, contributed more than half of the total nitrogen in 17 of 26 samples. Organic nitrogen is mineralized to nitrate and other forms of inorganic nitrogen in the presence of oxygen. Total nitrogen concentrations increased in samples from South Branch (01017980), B Stream (01018010), and Lowery Road (01018035) throughout the summer but were nearly constant in samples from Porter Settlement Road (01017970). Organic nitrogen concentrations were highest in early June and early August, which was when $\mathrm{NO}_{3}$ concentrations were least. Median concentrations of total nitrogen from all sampling events were higher in samples from downstream stations than upstream stations, but median concentrations of organic nitrogen and $\mathrm{NO}_{3}$ were not as consistent among the stations (fig. 5). Concentrations of nitrite + nitrate and filtered phosphorus in the replicate sample on April 24 were similar to those of the same constituents in the regular sample, indicating that concentrations observed in the regular sample were representative of concentrations in the stream at the time of sampling (table 5).

Meybeck (1982), as reported in Hem (1992), estimated that naturally occurring dissolved phosphorus in river water should average about $0.025 \mathrm{mg} / \mathrm{L}$. Concentrations of dissolved (filtered) phosphorus in Meduxnekeag River and tributaries were 0.004 to $0.012 \mathrm{mg} / \mathrm{L}$, with highest concentrations in samples from South Branch and Lowery Road (table 4). Peak concentrations of phosphorus were observed for all stations on
July 24 (the concentration in the sample from B Stream was estimated).

Data collected during this study indicate that Meduxnekeag River and tributaries were not seriously impaired during 2003 with respect to depletion of dissolved oxygen. Dissolved oxygen generally was near saturation, above 9 $\mathrm{mg} / \mathrm{L}$, during daylight hours when the samples were collected (table 6). Data on file with HBMI indicated reductions in dissolved oxygen during early morning or night hours when the photosynthetic production of aquatic plants is minimal but respiration is high (David Joseph, Houlton Band of Maliseet Indians, oral commun., 2002).

Measured $\mathrm{pH}$ was near neutral for all samples at all locations (table 6). The lowest $\mathrm{pH}$ recorded, 6.3, was measured during snowmelt runoff. During the rest of the spring and summer, $\mathrm{pH}$ was between 7.0 and 8.0.

In general, specific conductance increased at each station during the summer. The inverse relation between specific conductance and streamflow is common (Hem, 1992). Specific conductance was less at the B Stream station (01018010) than at the other three sampling stations.

\section{Nutrient Loads and Yields}

Instantaneous phosphorus load during the April 23-24 event was estimated as the sum of waterborne, filtered, total phosphorus (table 4) and phosphorus adsorbed to suspended sediment. Oliver and others (1999) showed that mechanisms of phosphorus adsorption to bed sediments and suspended

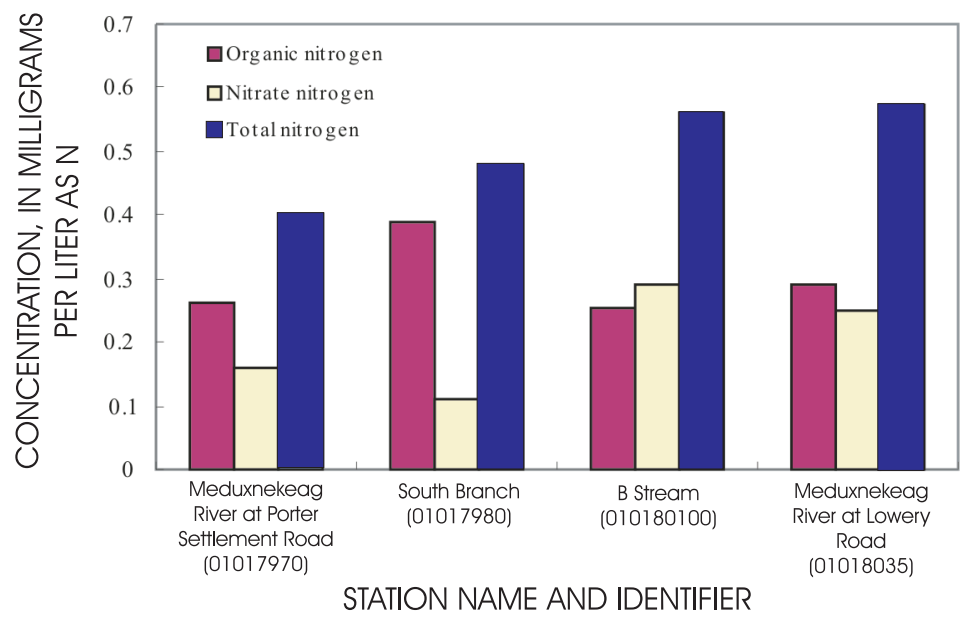

Figure 5. Median concentrations of nitrogen $(\mathrm{N})$ in surface-water samples from Meduxnekeag River watershed, Maine, AprilSeptember 2003. 
Table 4. Concentrations of selected nutrients in surface water, Meduxnekeag River watershed, Maine, April-September 2003. [N, nitrogen; $\mathrm{NH}_{3}$, ammonia; $\mathrm{NO}_{2}$, nitrite; $\mathrm{NO}_{3}$, nitrate; <, less than; E, estimated concentration; --, no data]

\begin{tabular}{|c|c|c|c|c|c|c|c|c|c|c|c|}
\hline \multirow[b]{2}{*}{$\begin{array}{l}\text { Sample } \\
\text { date }\end{array}$} & \multicolumn{11}{|c|}{ Concentration, in mlligrams per liter as $\mathbf{N}$ (nitrogen) or $\mathbf{P}$ (phosphorus) } \\
\hline & $\begin{array}{c}\text { Total N } \\
\text { unfiltered }\end{array}$ & $\begin{array}{l}\text { Total N } \\
\text { filtered }\end{array}$ & $\mathrm{NH}_{3}$ & $\mathrm{NO}_{2}$ & $\begin{array}{c}\mathrm{NH}_{3}+ \\
\text { organic } \\
\mathbf{N} \\
\text { filtered }\end{array}$ & $\begin{array}{c}\stackrel{\mathrm{NH}_{3}+}{\text { organic } \mathrm{N}} \\
\text { unfiltered }\end{array}$ & $\mathrm{NO}_{3}{ }^{\mathrm{a}}$ & $\begin{array}{c}\text { Organic } \\
\mathbf{N}^{\mathbf{b}}\end{array}$ & $\begin{array}{c}\text { Phosphorus } \\
\text { unfiltered }\end{array}$ & $\begin{array}{c}\text { Phosphorus } \\
\text { filtered }\end{array}$ & $\begin{array}{c}\text { Ortho- } \\
\text { phosphate }\end{array}$ \\
\hline & \multicolumn{11}{|c|}{ Station 01017970, Meduxnekeag River at Porter Settlement Road } \\
\hline $4 / 23 / 2003$ & 0.54 & -- & $<0.04$ & $<0.008$ & -- & 0.23 & 0.31 & 0.23 & $<0.04$ & $<0.04$ & $<0.02$ \\
\hline $5 / 30 / 2003$ & -- & 0.39 & -- & -- & 0.19 & -- & .20 & .19 & -- & E.004 & -- \\
\hline $6 / 2 / 2003$ & .42 & -- & $<.04$ & $<.008$ & -- & .31 & .10 & .31 & $<.04$ & $<.04$ & $<.02$ \\
\hline $6 / 18 / 2003$ & -- & .38 & -- & -- & .26 & -- & .13 & .26 & -- & .005 & -- \\
\hline $7 / 7 / 2003$ & -- & .44 & -- & -- & .26 & -- & .17 & .26 & -- & .005 & -- \\
\hline $7 / 24 / 2003$ & -- & .40 & -- & -- & .30 & -- & .10 & .30 & -- & .008 & -- \\
\hline \multirow[t]{2}{*}{$9 / 3 / 2003$} & -- & .40 & -- & -- & .24 & -- & .16 & .24 & -- & .005 & -- \\
\hline & \multicolumn{11}{|c|}{ Station 01017980, South Branch Meduxnekeag River } \\
\hline $4 / 23 / 2003$ & 0.37 & -- & $<0.04$ & $<0.008$ & -- & 0.26 & 0.11 & 0.26 & $<0.04$ & $<0.04$ & $<0.02$ \\
\hline $6 / 2 / 2003$ & .48 & -- & $<.04$ & $<.008$ & -- & .39 & .09 & .39 & $<.04$ & $<.04$ & $<.02$ \\
\hline $7 / 7 / 2003$ & -- & 0.60 & -- & -- & 0.37 & -- & .24 & .37 & -- & .008 & -- \\
\hline $7 / 24 / 2003$ & -- & .47 & -- & -- & .43 & -- & E.04 & .43 & -- & .010 & -- \\
\hline \multirow[t]{2}{*}{$9 / 3 / 2003$} & -- & .64 & -- & -- & .48 & -- & .16 & .48 & -- & .009 & -- \\
\hline & \multicolumn{11}{|c|}{ Station 01018010, B Stream } \\
\hline $4 / 24 / 2003$ & 0.44 & -- & $<0.04$ & $<0.008$ & -- & 0.26 & 0.18 & 0.26 & $<0.04$ & $<0.04$ & $<0.02$ \\
\hline $6 / 3 / 2003$ & .45 & -- & $<.04$ & $<.008$ & -- & .35 & .10 & .35 & $<.04$ & $<.04$ & $<.02$ \\
\hline $6 / 18 / 2003$ & -- & 0.51 & -- & -- & 0.26 & -- & .25 & .26 & -- & E.004 & -- \\
\hline $7 / 7 / 2003$ & -- & .63 & -- & -- & .29 & -- & .33 & .29 & -- & .004 & -- \\
\hline $7 / 24 / 2003$ & -- & .61 & -- & -- & .24 & -- & .37 & .24 & -- & E.004 & -- \\
\hline \multirow[t]{2}{*}{ 9/3/2003 } & -- & .75 & -- & -- & .25 & -- & .50 & .25 & -- & E.003 & -- \\
\hline & \multicolumn{11}{|c|}{ Station 01018035, Meduxnekeag River at Lowery Road } \\
\hline $4 / 24 / 2003$ & 0.52 & -- & $<0.04$ & $<0.008$ & -- & 0.24 & 0.28 & 0.24 & E0.02 & $<0.04$ & $<.02$ \\
\hline $5 / 30 / 2003$ & -- & 0.54 & -- & -- & 0.22 & -- & .32 & .22 & -- & .008 & -- \\
\hline $6 / 3 / 2003$ & .58 & -- & $<.04$ & $<.008$ & -- & .46 & .12 & .46 & $<.04$ & $<.04$ & $<.02$ \\
\hline $6 / 18 / 2003$ & -- & .50 & -- & -- & .28 & -- & .22 & .28 & -- & .008 & -- \\
\hline $7 / 7 / 2003$ & -- & .57 & -- & -- & .27 & -- & .30 & .27 & -- & .005 & -- \\
\hline $7 / 24 / 2003$ & -- & .59 & -- & -- & .42 & -- & .18 & .42 & -- & .012 & -- \\
\hline $8 / 6 / 2003$ & .67 & -- & $<.04$ & $<.008$ & -- & .62 & E.05 & .62 & E.02 & $<.04$ & $<.02$ \\
\hline $9 / 3 / 2003$ & -- & .73 & -- & -- & .30 & -- & .43 & .30 & -- & .006 & -- \\
\hline
\end{tabular}

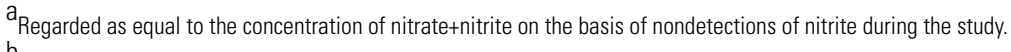

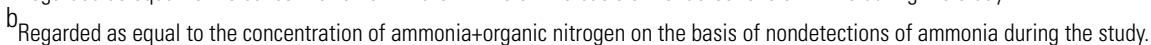


Table 5. Concentrations of selected nutrients in quality-assurance samples, Meduxnekeag River watershed, Maine, April and July 2003.

[ $\mathrm{NH}_{3}$, ammonia; $\mathrm{N}$, nitrogen; $\mathrm{NO}_{2}$, nitrite; $\mathrm{NO}_{3}$, nitrate; $\mathrm{P}$, phosphorus; $\mathrm{mg} / \mathrm{L}$, milligrams per liter; <, less than]

\begin{tabular}{ccllll}
\hline $\begin{array}{l}\text { Station } \\
\text { identifier } \\
\text { (Figure 2) }\end{array}$ & Date & $\begin{array}{l}\text { Sample } \\
\text { type }\end{array}$ & Nutrient & Concentration & Units \\
\hline 01017970 & $4 / 23 / 2003$ & Blank & $\mathrm{NH}_{3}$ & $<0.04$ & $\mathrm{mg} / \mathrm{L}$ as N \\
01017970 & $4 / 23 / 2003$ & Blank & $\mathrm{NO}_{2}$ & $<.008$ & $\mathrm{mg} / \mathrm{L}$ as N \\
01017970 & $4 / 23 / 2003$ & Blank & $\mathrm{NH}_{3}+$ organic $\mathrm{N}$ & $<.1$ & $\mathrm{mg} / \mathrm{L}$ as N \\
01017970 & $4 / 23 / 2003$ & Blank & $\mathrm{NO}_{2}+\mathrm{NO}_{3}$ & $<.06$ & $\mathrm{mg} / \mathrm{L}$ as N \\
01017970 & $4 / 23 / 2003$ & Blank & Phosphorus & $<.04$ & $\mathrm{mg} / \mathrm{L}$ \\
01017970 & $4 / 23 / 2003$ & Blank & Phosphorus & $<.04$ & $\mathrm{mg} / \mathrm{L}$ \\
01017970 & $4 / 23 / 2003$ & Blank & Orthophosphate & $<.02$ & $\mathrm{mg} / \mathrm{L}$ as P \\
01018035 & $4 / 24 / 2003$ & Replicate & $\mathrm{NO}_{2}+\mathrm{NO}_{3}$ & .27 & $\mathrm{mg} / \mathrm{L}$ as N \\
01018035 & $4 / 24 / 2003$ & Replicate & $\mathrm{Phosphorus}$ & .017 & $\mathrm{mg} / \mathrm{L}$ \\
01018035 & $7 / 07 / 2003$ & Blank & $\mathrm{NH}_{3}+$ organic $\mathrm{N}$ & $<.1$ & $\mathrm{mg} / \mathrm{L}$ as N \\
01018035 & $7 / 07 / 2003$ & Blank & $\mathrm{NO}_{2}+\mathrm{NO}_{3}$ & $<.06$ & $\mathrm{mg} / \mathrm{L}$ as N \\
01018035 & $7 / 07 / 2003$ & Blank & $\mathrm{Phosphorus}^{2}$ & $<.004$ & $\mathrm{mg} / \mathrm{L}$ \\
\hline
\end{tabular}

sediment are similar, although total amounts of phosphorus in bed sediments are generally higher than those in suspended sediment because of the number of soil grains available for binding. Instantaneous phosphorus load bound to suspended sediment $\left(\mathrm{PL}_{\mathrm{ss}}\right.$, in $\mathrm{kg} / \mathrm{d}$ (kilograms per day)) can be calculated from equation 1 :

$$
\mathrm{PL}_{\mathrm{ss}}=\mathrm{Ss} * \mathrm{P}_{\mathrm{ss}} * \mathrm{Q} * \mathrm{C}_{\mathrm{ss}}
$$

where Ss is the concentration of suspended sediment $(\mathrm{mg} / \mathrm{L})$, $\mathrm{P}_{\mathrm{ss}}$ is the concentration of phosphorus adsorbed to suspended sediment ( $\mathrm{mg} / \mathrm{kg}$ (milligrams per kilogram)), $\mathrm{Q}$ is the flow rate $\left(\mathrm{ft}^{3} / \mathrm{s}\right)$, and $\mathrm{C}_{\mathrm{ss}}$ is a unit-conversion factor of value $2.447 \mathrm{x}$ $10^{-6}$. Waterborne phosphorus load $\left(\mathrm{PL}_{\mathrm{w}}\right.$, in $\left.\mathrm{kg} / \mathrm{d}\right)$ is calculated from a similar equation:

$$
\mathrm{PL}_{\mathrm{w}}=\mathrm{P}_{\mathrm{w}} * \mathrm{Q} * \mathrm{C}_{\mathrm{w}}
$$

where $\mathrm{P}_{\mathrm{w}}$ is the concentration of phosphorus in water $(\mathrm{mg} / \mathrm{L})$ and $\mathrm{C}_{\mathrm{w}}$ is a unit-conversion factor of value 2.447 .

If it can be assumed (a) that phosphorus binds to suspended sediment at about the same concentrations as to bed sediment (that is, in the range of $200-600 \mathrm{mg} / \mathrm{kg}$, table 7) and (b) the concentrations of phosphorus in bed sediment in July, when bed sediment was sampled, were representative of those at other times the year, then at Lowery Road (01018035) on April 24, the instantaneous phosphorus load bound to suspended sediment was about $24 \mathrm{~kg} / \mathrm{d}$ by equation 1 :

$11 \mathrm{mg} / \mathrm{L} \mathrm{Ss}$ (table 3) * $230 \mathrm{mg} / \mathrm{kg} \mathrm{P} \mathrm{P}_{\mathrm{ss}}$ (table 7) * 3,820 $\mathrm{ft}^{3} / \mathrm{s}$ (table 6$) * 2.447 \times 10^{-6}=24 \mathrm{~kg} / \mathrm{d} \mathrm{PL} \mathrm{ss}$
Waterborne phosphorus load during high flow at Lowery Road was about $187 \mathrm{~kg} / \mathrm{d}$ total phosphorus:

$$
\begin{gathered}
0.02 \mathrm{mg} / \mathrm{L} \mathrm{P}_{\mathrm{w}}(\text { table } 4) * 3,820 \mathrm{ft}^{3} / \mathrm{s}(\text { table } 6) * 2.447 \\
=190 \mathrm{~kg} / \mathrm{d} \mathrm{PL}_{\mathrm{w}}
\end{gathered}
$$

Instantaneous phosphorus load during high flow, then, was about $210 \mathrm{~kg} / \mathrm{d}$, of which 89 percent was not bound to suspended sediment. Similar analyses were done for stations at Porter Settlement Road, South Branch, and B Stream on April 23-24; using estimated concentrations of total phosphorus equal to one-half the detection limit (Hornung and Reed, 1990) (table 4), instantaneous phosphorus loads were from 43 to 71 $\mathrm{kg} / \mathrm{d}$, of which 86 to 93 percent were not bound to suspended sediment.

Nitrogen loads and yields in surface water also were estimated similarly to phosphorus loads and yields; these estimates did not include sediment-bound nitrogen loads because nitrogen concentrations in sediment were not measured during the study. In these calculations, it was assumed that nitrogen concentrations were conservative and did not account for any in-stream processes that can affect nitrogen concentrations, such as plant uptake and denitrification. Instantaneous loads of organic nitrogen and $\mathrm{NO}_{3}$ were calculated by an equation analogous to equation 2 for the April 23-24 and June 2-3 sampling events (table 8) for four watersheds: B Stream $\left(\mathrm{L}_{\mathrm{B}}\right.$, using flows and concentrations measured at 01018010), South Branch ( $\mathrm{L}_{\mathrm{SB}}$, using flows and concentrations measured at 01017980), Meduxnekeag River above Porter Settlement Road ( $\mathrm{L}_{\mathrm{PS}}$, using flows and concentrations measured at 01017970), and Meduxnekeag River above Lowery Road $\left(\mathrm{L}_{\mathrm{LR}}\right.$, using flows and concentrations measured at 01018035). Loads were calculated for Meduxnekeag River between Porter Settlement 
12 Nutrients, Organic Compounds, and Mercury in the Meduxnekeag River Watershed, Maine, 2003

Table 6. Streamflow and physical properties, Meduxnekeag River watershed, Maine, April-September 2003.

$\left[{ }^{0} \mathrm{C}\right.$, Celsius; --, no data]

\begin{tabular}{|c|c|c|c|c|c|c|c|c|c|}
\hline $\begin{array}{l}\text { Sample } \\
\text { date }\end{array}$ & $\begin{array}{l}\text { Instant- } \\
\text { aneous } \\
\text { discharge, } \\
\text { in cubic } \\
\text { feet per } \\
\text { second }\end{array}$ & $\begin{array}{c}\text { Gage } \\
\text { height, in } \\
\text { feet (tape- } \\
\text { down value } \\
\text { from } \\
\text { reference } \\
\text { mark) }\end{array}$ & $\begin{array}{l}\text { Water } \\
\text { temper- } \\
\text { ature, in } \\
{ }^{0} \mathrm{C}\end{array}$ & $\begin{array}{c}\text { Air } \\
\text { temper- } \\
\text { ature), in } \\
{ }^{0} \mathrm{C}\end{array}$ & $\begin{array}{c}\text { Barometric } \\
\text { pressure, in } \\
\text { millimeters } \\
\text { of mercury }\end{array}$ & $\begin{array}{c}\text { Specific } \\
\text { conduct- } \\
\text { ance, in } \\
\text { micro- } \\
\text { siemens } \\
\text { per } \\
\text { centimeter } \\
\text { at } 25^{\circ} \mathrm{C}\end{array}$ & $\begin{array}{c}\text { Dissolved } \\
\text { oxygen, in } \\
\text { milligrams } \\
\text { per liter }\end{array}$ & $\begin{array}{l}\text { Dissolved } \\
\text { oxygen, in } \\
\text { percent of } \\
\text { saturation }\end{array}$ & $\begin{array}{c}\text { pH, in } \\
\text { standard } \\
\text { units }\end{array}$ \\
\hline \multicolumn{10}{|c|}{ Station 01017970, Meduxnekeag River at Porter Settlement Road } \\
\hline $4 / 23 / 2003$ & 1,340 & -11.00 & 2 & -- & 742 & 87 & 12.2 & 91 & 6.8 \\
\hline $5 / 30 / 2003$ & -- & -14.91 & 15.3 & 18.2 & -- & 177 & 9.8 & -- & 7.5 \\
\hline $6 / 2 / 2003$ & -- & -13.81 & 15.4 & -- & 740 & 160 & 9.9 & 100 & 7.6 \\
\hline $6 / 4 / 2003^{\mathrm{a}}$ & 184 & -14.39 & -- & -- & -- & -- & -- & -- & -- \\
\hline $6 / 18 / 2003$ & -- & -14.75 & -- & -- & -- & -- & -- & -- & -- \\
\hline $7 / 7 / 2003$ & -- & -15.4 & -- & -- & -- & 216 & -- & -- & 7.8 \\
\hline $7 / 24 / 2003$ & -- & -15.10 & -- & -- & -- & -- & -- & -- & -- \\
\hline \multicolumn{10}{|c|}{ Station 01017980, South Branch Meduxnekeag River } \\
\hline $4 / 23 / 2003$ & 963 & -- & 0.6 & $\begin{array}{ll}- \\
-\end{array}$ & 742 & 48 & 13.3 & 95 & 6.9 \\
\hline $6 / 2 / 2003$ & -- & -- & 16.1 & -- & 740 & 107 & 9.7 & 101 & 7.5 \\
\hline $6 / 4 / 2003^{\mathrm{a}}$ & 195 & -- & -- & -- & -- & -- & -- & -- & -- \\
\hline $7 / 7 / 2003$ & -- & 0.71 & -- & -- & -- & 169 & -- & -- & 7.6 \\
\hline $7 / 24 / 2003$ & -- & .00 & -- & -- & -- & -- & -- & -- & -- \\
\hline $9 / 3 / 2003$ & -- & .07 & -- & -- & -- & -- & -- & -- & -- \\
\hline \multicolumn{10}{|c|}{ Station 01018010, B Stream } \\
\hline $4 / 24 / 2003$ & 791 & -19.49 & 1.1 & -- & 740 & 53 & 13 & 95 & 6.5 \\
\hline $6 / 3 / 2003$ & 135 & -21.87 & 12.2 & -- & 748 & 82 & 10.5 & 100 & 7.4 \\
\hline $6 / 18 / 2003$ & -- & -22.5 & -- & -- & -- & -- & -- & -- & -- \\
\hline $7 / 7 / 2003$ & -- & -22.8 & -- & -- & -- & 164 & -- & -- & 7.4 \\
\hline $7 / 24 / 2003$ & -- & -23.30 & -- & -- & -- & -- & -- & -- & -- \\
\hline $9 / 3 / 2003$ & -- & -22.85 & -- & -- & -- & -- & -- & -- & -- \\
\hline \multicolumn{10}{|c|}{ Station 01018035, Meduxnekeag River at Lowery Road } \\
\hline $4 / 24 / 2003$ & 3,820 & -16.46 & 1.6 & -- & 740 & 80 & 12.9 & 95 & 6.3 \\
\hline $5 / 30 / 2003$ & -- & -21.03 & 15 & 18.8 & -- & 204 & 10.4 & -- & 7.5 \\
\hline $6 / 3 / 2003$ & -- & -19.98 & 14.8 & 15.6 & 747 & 127 & 10.9 & -- & 7.6 \\
\hline $6 / 4 / 2003^{\mathrm{a}}$ & 586 & -20.37 & -- & -- & -- & -- & -- & -- & -- \\
\hline $6 / 18 / 2003$ & -- & -21.19 & -- & -- & -- & -- & -- & -- & -- \\
\hline $7 / 7 / 2003$ & -- & -21.77 & -- & -- & -- & 220 & -- & -- & 8.2 \\
\hline $7 / 17 / 2003$ & -- & -21.95 & -- & -- & -- & -- & -- & -- & -- \\
\hline $7 / 24 / 2003$ & -- & -20.85 & -- & -- & -- & -- & -- & -- & -- \\
\hline $8 / 6 / 2003$ & -- & -16.86 & -- & -- & -- & -- & -- & -- & -- \\
\hline $9 / 3 / 2003$ & -- & -21.78 & -- & -- & -- & -- & -- & -- & -- \\
\hline
\end{tabular}

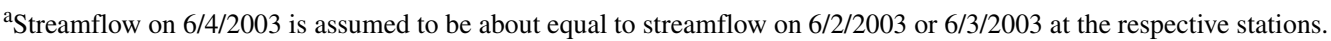


Table 7. Concentrations of phosphorus in bed sediment, Meduxnekeag River watershed, Maine, July 2003.

\begin{tabular}{|c|c|c|}
\hline $\begin{array}{l}\text { Station identifier } \\
\text { (Figure 2) }\end{array}$ & Sample date & $\begin{array}{l}\text { Concentration, } \\
\text { in milligrams } \\
\text { per kilogram }\end{array}$ \\
\hline 01017970 & $7 / 16 / 2003$ & 230 \\
\hline 01017980 & $7 / 16 / 2003$ & 180 \\
\hline 01018010 & $7 / 17 / 2003$ & 270 \\
\hline 01018012 & $7 / 17 / 2003$ & 490 \\
\hline 01018015 & $7 / 17 / 2003$ & 210 \\
\hline 01018018 & $7 / 17 / 2003$ & 660 \\
\hline 01018020 & 7/17/2003 & 530 \\
\hline 01018034 & 7/17/2003 & 630 \\
\hline 01018035 & $7 / 17 / 2003$ & 230 \\
\hline
\end{tabular}

Road and Lowery Road $\left(\mathrm{L}_{\mathrm{PL}}\right)$, hereafter called the Houlton area for convenience, by subtraction:

$$
L_{P L}=L_{L R}-L_{P S}-L_{S B}-L_{B}
$$

The Houlton area includes Houlton's wastewater-treatment facility and Pearce, Jimmy, Cook, and Smith Brooks (fig. 2).

During the April 23-24 event, combined loads of organic and $\mathrm{NO}_{3}$ nitrogen at Porter Settlement Road (01017970), South Branch (01017980), and B Stream (01018010) were about 83 and 67 percent, respectively, of the loads at Lowery Road (01018035), whereas combined streamflow at the three upstream stations was about 81 percent of the streamflow at Lowery Road and combined drainage area about
86 percent. By equation 3, 33 percent of the $\mathrm{NO}_{3}$ load at Lowery Road came from the Houlton area, which represents 14 percent of the total drainage area. These data indicate that the Houlton area contributed high concentrations of $\mathrm{NO}_{3}$ to Meduxnekeag River at Lowery Road during the high flows on April 23-24.

During the June 2-3 sampling event (using streamflows measured on June 4), the same subwatersheds contributed 67 and 70 percent of the loads of organic and $\mathrm{NO}_{3}$ nitrogen, respectively, to Lowery Road but 87 percent of its streamflow (table 8, figure 6). At medium flow, then, the Houlton area contributed high loads of both organic and $\mathrm{NO}_{3}$ nitrogen. Minimally changing flow conditions during the 2 to 3 days of data collection may have affected the results of this analysis.

Nutrient yields are loads that are normalized for drainage area. Because drainage area frequently is a primary contributor to streamflow (see, for example, Dudley, 2004), this normalization process provides estimates of the contribution of nutrients from a subwatershed that are not dependent upon the size of the stream or its watershed. Nitrogen yields were higher on April 23-24 than on June 2-3 (table 8). During the April 23-24 event, total nitrogen yields were lowest at the South Branch station, whereas during the June 2-3 event, yields were lowest at the Porter Settlement Road station. During both events, total nitrogen yields at B Stream were similar to those from the entire watershed, as measured at Lowery Road, and organic nitrogen yields at B Stream were greatest. Research has shown that nitrogen yields often are higher in early spring than during other times of the year

Table 8. Instantaneous nitrogen loads and yields at selected stations in Meduxnekeag River watershed, Maine, April and June 2003. [mi², square miles; $\mathrm{ft}^{3} / \mathrm{s}$, cubic feet per second; $\mathrm{mg} / \mathrm{L}$, milligrams per liter; $\mathrm{kg} / \mathrm{d}$, kilograms per day; $\mathrm{N}$, nitrogen]

\begin{tabular}{|c|c|c|c|c|c|c|c|c|c|c|c|}
\hline \multirow{2}{*}{$\begin{array}{l}\text { Station } \\
\text { identifier } \\
\text { (Figure 2) }\end{array}$} & \multirow{2}{*}{$\begin{array}{c}\text { Drainage } \\
\text { area } \\
\left(\mathrm{mi}^{2}\right)\end{array}$} & \multirow{2}{*}{$\begin{array}{c}\text { Stream- } \\
\text { flow } \\
\left(\mathrm{ft}^{3} / \mathrm{s}\right)\end{array}$} & \multicolumn{3}{|c|}{ Concentration (mg/L as $\mathrm{N}$ ) } & \multicolumn{3}{|c|}{ Load (kg/d) } & \multicolumn{3}{|c|}{ Yield (kg/d-mi $\left.{ }^{2}\right)$} \\
\hline & & & $\begin{array}{c}\text { Total } \\
\mathbf{N}\end{array}$ & $\underset{N}{\text { Organic }}$ & $\begin{array}{c}\text { Nitrate } \\
\mathbf{N}\end{array}$ & $\begin{array}{c}\text { Total } \\
\mathbf{N}\end{array}$ & $\underset{\mathbf{N}}{\text { Organic }}$ & $\begin{array}{c}\text { Nitrate } \\
\mathbf{N}\end{array}$ & $\begin{array}{c}\text { Total } \\
\mathbf{N}\end{array}$ & $\underset{N}{\operatorname{Organic}}$ & $\begin{array}{c}\text { Nitrate } \\
\text { N }\end{array}$ \\
\hline \multicolumn{12}{|c|}{ April 23-24, 2003} \\
\hline 01017970 & 106 & 1,340 & 0.54 & 0.23 & 0.31 & 1,770 & 750 & 1,020 & 16.7 & 7.1 & 9.6 \\
\hline 01017980 & 69 & 963 & .37 & .26 & .11 & 870 & 610 & 260 & 12.6 & 8.9 & 3.8 \\
\hline 01018010 & 45 & 791 & .44 & .26 & .18 & 850 & 500 & 350 & 18.9 & 11.2 & 7.7 \\
\hline 01018035 & 257 & 3,820 & .52 & .24 & .26 & 4,860 & 2,240 & 2,430 & 18.9 & 8.7 & 9.5 \\
\hline \multicolumn{12}{|c|}{ June $2-3,2003$} \\
\hline 01017970 & 106 & 184 & 0.42 & 0.31 & 0.10 & 190 & 140 & 45 & 1.8 & 1.3 & 0.42 \\
\hline 01017980 & 69 & 195 & .48 & .39 & .09 & 230 & 190 & 43 & 3.3 & 2.7 & .62 \\
\hline 01018010 & 45 & 135 & .45 & .35 & .10 & 150 & 120 & 33 & 3.3 & 2.6 & .73 \\
\hline 01018035 & 257 & 586 & .58 & .46 & .12 & 830 & 660 & 170 & 3.2 & 2.6 & .67 \\
\hline
\end{tabular}




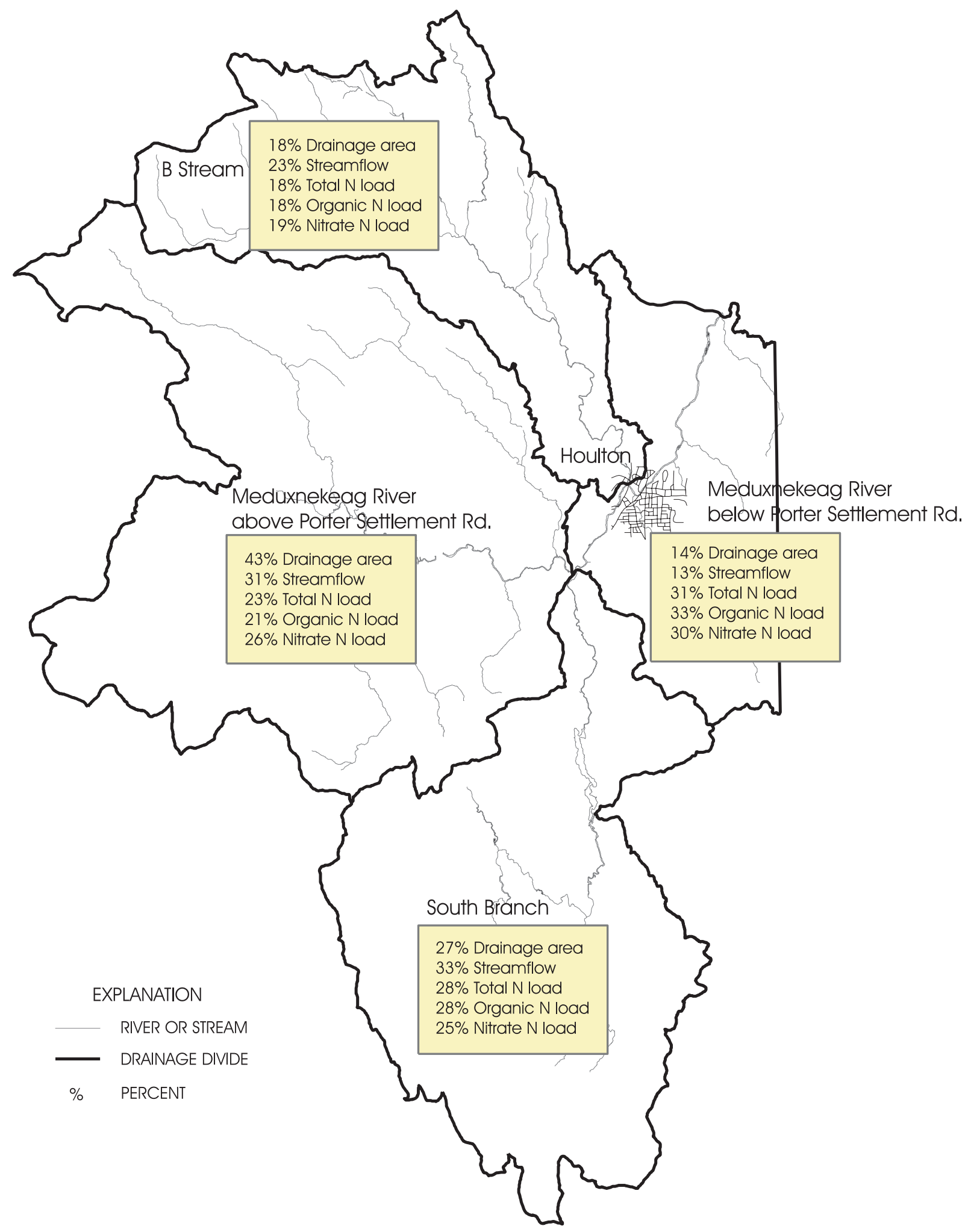

Figure 6 . Streamflows and nitrogen (N) loads, Meduxnekeag River subwatershed, Maine, June 2-3, 2003. 
because of high runoff volumes from snowmelt (Kaushal and Lewis, 2003; U.S. Geological Survey, 1999).

\section{Bed Sediments}

Bed sediments were sampled at three main-stem stations (01017970, 01018015, and 01018035) and selected tributaries to infer potential nutrient flux from sediments to Meduxnekeag River. Fine-grained bed sediments were uncommon in the river. U.S. Department of Agriculture classifies particles with diameters less than $0.002 \mathrm{~mm}$ as clays, particles with diameters from $0.002 \mathrm{~mm}$ to $0.05 \mathrm{~mm}$ as silts, and particles with diameters from $0.05 \mathrm{~mm}$ to $2 \mathrm{~mm}$ as sands (Hillel, 1982). Sediments at all three stations were classified as sands, containing more than 95 percent particles greater than $0.063 \mathrm{~mm}$ diameter (table 9). Chemicals such as nutrients and organic compounds generally bond readily to clays because of their electrochemical nature and available surface area; in comparison to clays, sands and silts are relatively inert. Because of the high percentage of sand present in samples, the sediments at the seven sampling stations probably do not retain chemicals at concentrations as high as those that might be found in silty or muddy streams.

Phosphorus was detected in all nine bed-sediment samples at concentrations from 180 to $660 \mathrm{mg} / \mathrm{kg}$ (table 7). The lowest concentration was in the sample from South Branch, whereas the highest concentrations -2 to 3 times as high as the others-were in the samples from the small tributaries of Pearce, Jimmy, Cook, and Smith Brooks (which were not analyzed for particle-size distribution). Given that streambeds in the study area contain generally large-diameter sands, which are less mobile than silts and clays, and that the brooks each have small drainage basins (table 1), phosphorus may accumulate in the sediments of these tributaries because of insufficient scouring events.

According to recent studies, phosphorus concentrations in bed sediments of Meduxnekeag River generally were lower than those in sediments of rivers nearby. Median concentrations of phosphorus in sediments of the lower Charles and upper Mystic Rivers in Massachusetts were $1,500 \mathrm{mg} / \mathrm{kg}$ and $1,200 \mathrm{mg} / \mathrm{kg}$, respectively (Breault and others, 2000; Breault and others, 2004). The relatively low concentrations of phosphorus in sediments of Meduxnekeag River, combined with the high concentrations of dissolved oxygen observed throughout the study, inhibited the release of phosphorus from the streambed. If release of phosphorus from sediments is a source of nutrients that supports algal blooms, as presented as a working hypothesis in the introduction to this report, the optimal conditions for this to occur were not observed during the summer of 2003.

Concentrations of mercury and carbon in bed sediment decreased with distance downstream from Porter Settlement Road (01017970). Mercury was detected in all three bed-sediment samples for which it was analyzed at concentrations from 0.06 to $0.2 \mu \mathrm{g} / \mathrm{g}$ (table 10, back of report). Fish-consumption advisories have been issued for mercury in Meduxnekeag River (Maine Department of Inland Fisheries and Wildlife, 2003). Concentrations of organic and inorganic carbon also were detected in all three samples, and concentrations of organic carbon were greater than those of inorganic carbon. Concentrations of mercury increased with concentrations of organic carbon in samples (fig. 7).

Table 9. Bed-sediment particle-size distributions, Meduxnekeag River, Maine, July 2003. [mm, millimeters; $<$, less than; $>$, greater than; $\%$, percent. Samples were field-sieved to $<2 \mathrm{~mm}$.]

\begin{tabular}{|c|c|c|c|c|c|c|c|}
\hline $\begin{array}{l}\text { Station } \\
\text { identifier } \\
\text { (Figure 2) }\end{array}$ & $\begin{array}{l}\text { Percent by } \\
\text { weight } \\
<1 \mathrm{~mm}\end{array}$ & $\begin{array}{l}\text { Percent by } \\
\text { weight } \\
<0.5 \mathrm{~mm}\end{array}$ & $\begin{array}{l}\text { Percent by } \\
\text { weight } \\
<0.25 \mathrm{~mm}\end{array}$ & $\begin{array}{l}\text { Percent by } \\
\text { weight } \\
<0.125 \mathrm{~mm}\end{array}$ & $\begin{array}{l}\text { Percent by } \\
\text { weight } \\
<0.063 \mathrm{~mm}\end{array}$ & $\begin{array}{l}\text { Percent by } \\
\text { weight } \\
<0.004 \mathrm{~mm}\end{array}$ & $\begin{array}{l}\text { Percent } \\
\text { sand by } \\
\text { weight, } \\
>0.063 \mathrm{~mm}\end{array}$ \\
\hline 01017970 & 29.93 & 38.43 & 18.11 & 5.84 & 3.03 & 1.1 & 95.9 \\
\hline 01018015 & 34.78 & 39.96 & 16.96 & 4.40 & 1.41 & .5 & 98.1 \\
\hline 01018035 & 52.24 & 36.60 & 6.78 & 1.67 & .94 & .4 & 98.7 \\
\hline
\end{tabular}




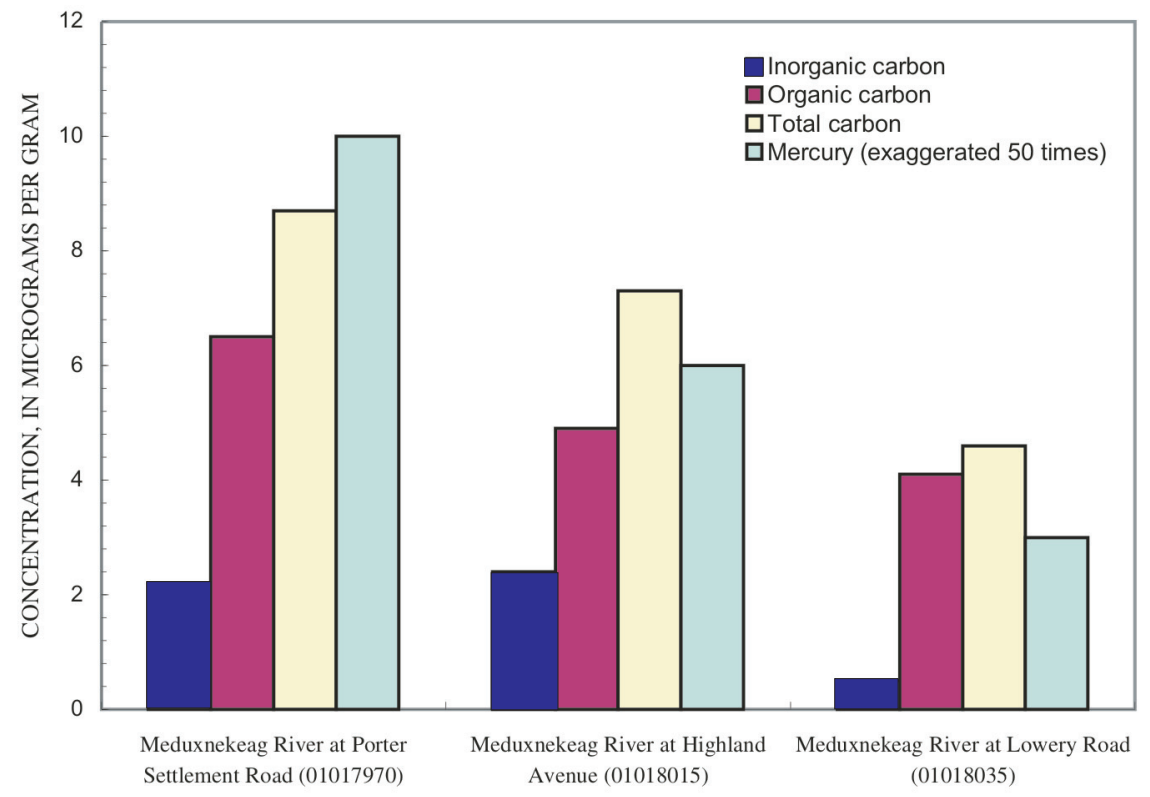

STATION NAME AND IDENTIFIER

Figure 7 . Concentrations of carbon and mercury at stations on Meduxnekeag River, Maine, July 2003.

Bed-sediment samples did not contain detectable concentrations of PCBs or phthalate esters (table 10). The only phenolic compound detected was p-cresol, at concentrations ranging from $130 \mathrm{E}$ to $140 \mathrm{E} \mu \mathrm{g} / \mathrm{kg}$ (micrograms per kilogram). Metabolites of the DDT pesticide family, p,p'-DDE and p,p'DDT, were detected in samples from Porter Settlement Road and Highland Avenue at concentrations from 4 (estimated) to $13 \mu \mathrm{g} / \mathrm{kg}$. No other pesticides were detected. Fish-consumption advisories for DDT in Meduxnekeag River have been issued (Maine Department of Inland Fisheries and Wildlife, 2003).
Polycyclic aromatic hydrocarbons (PAHs) detected in bed-sediment samples included pyrene, fluorene, fluoranthene, naphthalene, phenanthrene, anthracene, and many of their derivatives (table 10). The sum of concentrations of PAHs in the sample from Highland Avenue (01018015) was nearly three times as high as that in the sample from Porter Settlement Road and nearly four times as high as that in the sample from Lowery Road (fig. 8), possibly reflecting the proximity of Highland Avenue to urban processes that generate many of these organic compounds. The eight highest concentrations of

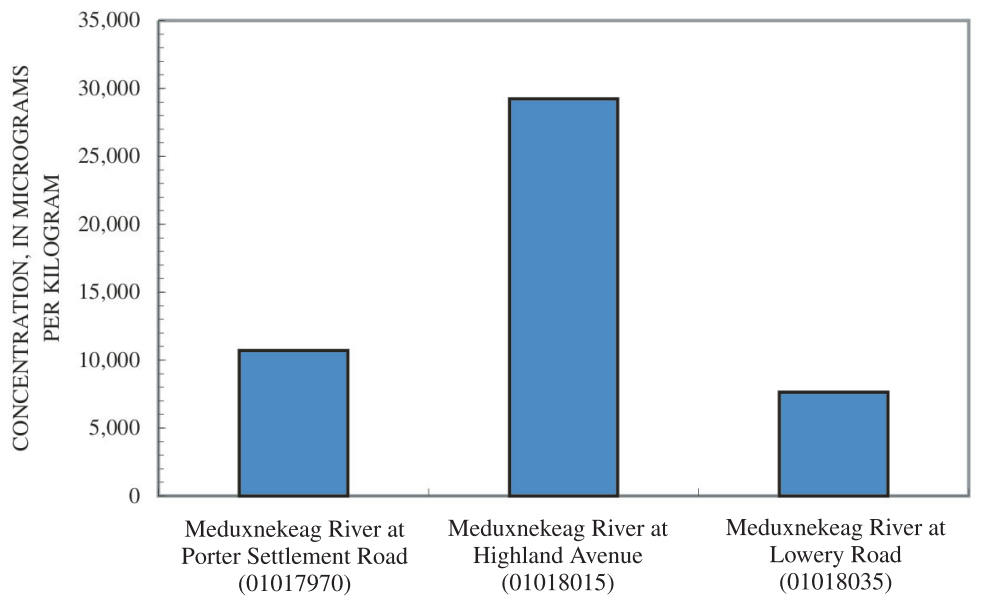

STATION NAME AND IDENTIFIER

Figure 8. Sum of concentrations of polycyclic aromatic hydrocarbons in bed-sediment samples from Meduxnekeag River, July 2003. 
Table 10. Concentrations of mercury, carbon, and hydrophobic organic compounds in bed sediment, Meduxnekeag River, Maine, July 2003.

$[\mu \mathrm{g} / \mathrm{kg}$, micrograms per kilogram; $\mu \mathrm{g} / \mathrm{g}$, micrograms per gram; $\mathrm{g} / \mathrm{kg}$, grams per kilogram; <, less than; $\mathrm{n}$, number of samples; E, estimated; --, no data; NECB NAWQA, New England Coastal Basins National Water-Quality Assessment]

\begin{tabular}{|c|c|c|c|c|c|}
\hline \multirow[b]{3}{*}{ Compound } & \multirow[b]{3}{*}{ Units } & \multicolumn{3}{|c|}{ Station identifier and sample date } & \multirow{3}{*}{$\begin{array}{l}\text { Median from } \\
\text { NECB } \\
\text { NAWQA } \\
\text { ( } n=14 \text { for } \\
\text { organics and } \\
\text { carbon, } n=63 \\
\text { for mercury) }\end{array}$} \\
\hline & & $\begin{array}{l}01017970 \\
7 / 16 / 2003\end{array}$ & $\begin{array}{l}01018015 \\
7 / 17 / 2003\end{array}$ & $\begin{array}{l}01018035 \\
7 / 17 / 2003\end{array}$ & \\
\hline & & \multicolumn{3}{|c|}{ Concentration } & \\
\hline Mercury & $\mu \mathrm{g} / \mathrm{g}$ & 0.2 & 0.12 & 0.06 & 0.12 \\
\hline Inorganic carbon & $\mathrm{g} / \mathrm{kg}$ & 2.2 & 2.4 & .5 & $<2$ \\
\hline Organic carbon & $\mathrm{g} / \mathrm{kg}$ & 6.5 & 4.9 & 4.1 & 62 \\
\hline Total carbon & $\mathrm{g} / \mathrm{kg}$ & 8.7 & 7.3 & 4.6 & 62 \\
\hline \multicolumn{6}{|c|}{ Organic surrogates } \\
\hline a-HCH-d6 & percent & 71 & 77 & 61 & 72 \\
\hline Terphenyl-d14 & percent & 110 & 90 & 87 & 72 \\
\hline 2-Fluorobiphenyl & percent & 94 & 83 & 72 & 60 \\
\hline Nitrobenzene-d5 & percent & 110 & 88 & 96 & 61 \\
\hline \multicolumn{6}{|c|}{ Pesticides } \\
\hline cis-Nonachlor & $\mu \mathrm{g} / \mathrm{kg}$ & $<5$ & $<5$ & $<5$ & 2 \\
\hline trans-Nonachlor & $\mu \mathrm{g} / \mathrm{kg}$ & $<5$ & $<5$ & $<5$ & 6 \\
\hline Oxychlordane & $\mu \mathrm{g} / \mathrm{kg}$ & $<5$ & $<5$ & $<5$ & $<2$ \\
\hline Aldrin & $\mu \mathrm{g} / \mathrm{kg}$ & $<5$ & $<5$ & $<5$ & $<2$ \\
\hline cis-Chlordane & $\mu \mathrm{g} / \mathrm{kg}$ & $<5$ & $<5$ & $<5$ & 7 \\
\hline trans-Chlordane & $\mu \mathrm{g} / \mathrm{kg}$ & $<5$ & $<5$ & $<5$ & 5 \\
\hline Chloroneb & $\mu \mathrm{g} / \mathrm{kg}$ & $<25$ & $<25$ & $<25$ & $<10$ \\
\hline Dacthal & $\mu \mathrm{g} / \mathrm{kg}$ & $<25$ & $<25$ & $<25$ & $<10$ \\
\hline o,p'-DDD & $\mu \mathrm{g} / \mathrm{kg}$ & $<5$ & $<5$ & $<5$ & $<2$ \\
\hline p,p'-DDD & $\mu \mathrm{g} / \mathrm{kg}$ & $<5$ & $<5$ & $<5$ & 13 \\
\hline o,p'-DDE & $\mu \mathrm{g} / \mathrm{kg}$ & $<5$ & $<5$ & $<5$ & $<2$ \\
\hline $\mathrm{p}, \mathrm{p}$ '-DDE & $\mu \mathrm{g} / \mathrm{kg}$ & $\mathrm{E} 4$ & 5 & $<5$ & 8 \\
\hline o,p'-DDT & $\mu \mathrm{g} / \mathrm{kg}$ & $<10$ & $<10$ & $<10$ & $<4$ \\
\hline p,p'-DDT & $\mu \mathrm{g} / \mathrm{kg}$ & 13 & $<10$ & $<10$ & 6 \\
\hline Dieldrin & $\mu \mathrm{g} / \mathrm{kg}$ & $<5$ & $<5$ & $<5$ & 2 \\
\hline alpha-Endosulfan & $\mu \mathrm{g} / \mathrm{kg}$ & $<5$ & $<5$ & $<5$ & $<2$ \\
\hline Endrin & $\mu \mathrm{g} / \mathrm{kg}$ & $<10$ & $<10$ & $<10$ & $<4$ \\
\hline alpha-Hexachlorocyclohexane & $\mu \mathrm{g} / \mathrm{kg}$ & $<5$ & $<5$ & $<5$ & $<2$ \\
\hline beta-Hexachlorocyclohexane & $\mu \mathrm{g} / \mathrm{kg}$ & $<5$ & $<5$ & $<5$ & $<2$ \\
\hline Heptachlor & $\mu \mathrm{g} / \mathrm{kg}$ & $<5$ & $<5$ & $<5$ & $<2$ \\
\hline Heptachlor epoxide & $\mu \mathrm{g} / \mathrm{kg}$ & $<5$ & $<5$ & $<5$ & $<2$ \\
\hline Hexachlorobenzene & $\mu \mathrm{g} / \mathrm{kg}$ & $<5$ & $<5$ & $<5$ & $<2$ \\
\hline Isodrin & $\mu \mathrm{g} / \mathrm{kg}$ & $<5$ & $<5$ & $<5$ & $<2$ \\
\hline Lindane & $\mu \mathrm{g} / \mathrm{kg}$ & $<5$ & $<5$ & $<5$ & $<2$ \\
\hline p,p'-Methoxychlor & $\mu \mathrm{g} / \mathrm{kg}$ & $<25$ & $<25$ & $<25$ & $<10$ \\
\hline o,p'-Methoxychlor & $\mu \mathrm{g} / \mathrm{kg}$ & $<25$ & $<25$ & $<25$ & $<10$ \\
\hline Mirex & $\mu \mathrm{g} / \mathrm{kg}$ & $<5$ & $<5$ & $<5$ & $<2$ \\
\hline cis-Permethrin & $\mu \mathrm{g} / \mathrm{kg}$ & $<25$ & $<25$ & $<25$ & $<10$ \\
\hline trans-Permethrin & $\mu \mathrm{g} / \mathrm{kg}$ & $<25$ & $<25$ & $<25$ & $<10$ \\
\hline Toxaphene & $\mu \mathrm{g} / \mathrm{kg}$ & $<1,000$ & $<1,000$ & $<1,000$ & $<400$ \\
\hline
\end{tabular}


Table 10. Concentrations of mercury, carbon, and hydrophobic organic compounds in bed sediment, Meduxnekeag River, Maine, July 2003._-Continued

$[\mu \mathrm{g} / \mathrm{kg}$, micrograms per kilogram; $\mu \mathrm{g} / \mathrm{g}$, micrograms per gram; $\mathrm{g} / \mathrm{kg}$, grams per kilogram; <, less than; $\mathrm{n}$, number of samples; E, estimated; --, no data; NECB NAWQA, New England Coastal Basins National Water-Quality Assessment]

\begin{tabular}{|c|c|c|c|c|c|}
\hline \multirow[b]{3}{*}{ Compound } & \multirow[b]{3}{*}{ Units } & \multicolumn{3}{|c|}{ Station identifier and sample date } & \multirow{3}{*}{$\begin{array}{l}\text { Median from } \\
\text { - NECB } \\
\text { NAWOA } \\
\text { ( } n=14 \text { for } \\
\text { organics and } \\
\text { carbon, } n=63 \\
\text { for mercury) }\end{array}$} \\
\hline & & $\begin{array}{l}01017970 \\
7 / 16 / 2003\end{array}$ & $\begin{array}{l}01018015 \\
7 / 17 / 2003\end{array}$ & $\begin{array}{l}01018035 \\
7 / 17 / 2003\end{array}$ & \\
\hline & & \multicolumn{3}{|c|}{ Concentration } & \\
\hline \multicolumn{6}{|c|}{ Phthalate esters } \\
\hline Dibutyl phthalate & $\mu \mathrm{g} / \mathrm{kg}$ & $<300$ & $<300$ & $<300$ & 94 \\
\hline Dioctyl phthalate & $\mu \mathrm{g} / \mathrm{kg}$ & $<300$ & $<300$ & $<300$ & $<100$ \\
\hline Diethyl phthalate & $\mu \mathrm{g} / \mathrm{kg}$ & $<300$ & $<300$ & $<300$ & $<100$ \\
\hline Dimethyl Phthalate & $\mu \mathrm{g} / \mathrm{kg}$ & $<300$ & $<300$ & $<300$ & $<100$ \\
\hline 2-Ethylhexylphthalate & $\mu \mathrm{g} / \mathrm{kg}$ & $<300$ & $<300$ & $<300$ & 1,300 \\
\hline Butylbenzylphthalate & $\mu \mathrm{g} / \mathrm{kg}$ & $<300$ & $<300$ & $<300$ & 150 \\
\hline \multicolumn{6}{|c|}{ Polycyclic aromatic hydrocarbons } \\
\hline Acenaphthylene & $\mu \mathrm{g} / \mathrm{kg}$ & 320 & 360 & E180 & 210 \\
\hline Acenaphthene & $\mu \mathrm{g} / \mathrm{kg}$ & E51 & E130 & E39 & $<100$ \\
\hline Anthracene & $\mu \mathrm{g} / \mathrm{kg}$ & 330 & 790 & E200 & 425 \\
\hline 2-Methylanthracene & $\mu \mathrm{g} / \mathrm{kg}$ & E130 & E230 & E96 & 100 \\
\hline Benz[a]anthracene & $\mu \mathrm{g} / \mathrm{kg}$ & 830 & 2,400 & 660 & 1,550 \\
\hline Chrysene & $\mu \mathrm{g} / \mathrm{kg}$ & 880 & 2,600 & 640 & 205 \\
\hline Pyrene & $\mu \mathrm{g} / \mathrm{kg}$ & 1,500 & 4,400 & 880 & 3,100 \\
\hline 1-Methylpyrene & $\mu \mathrm{g} / \mathrm{kg}$ & E190 & 310 & E120 & 160 \\
\hline Benzo[a]pyrene & $\mu \mathrm{g} / \mathrm{kg}$ & 680 & 2,000 & 520 & 1,400 \\
\hline Dibenz[ah]anthracene & $\mu \mathrm{g} / \mathrm{kg}$ & E260 & 480 & E240 & 220 \\
\hline Fluoranthene & $\mu \mathrm{g} / \mathrm{kg}$ & 1,600 & 5,400 & 1,100 & 3,750 \\
\hline Indenopyrene & $\mu \mathrm{g} / \mathrm{kg}$ & 620 & 1,400 & 520 & 870 \\
\hline Benzo[k]fluoranthene & $\mu \mathrm{g} / \mathrm{kg}$ & 630 & 1,900 & 560 & 1,450 \\
\hline 1-Methylfluorene & $\mu \mathrm{g} / \mathrm{kg}$ & E68 & E100 & E62 & $<100$ \\
\hline Fluorene & $\mu \mathrm{g} / \mathrm{kg}$ & E93 & E220 & E72 & 150 \\
\hline Naphthalene & $\mu \mathrm{g} / \mathrm{kg}$ & E62 & E92 & E60 & $<100$ \\
\hline 1,2-Dimethlnaphthalene & $\mu \mathrm{g} / \mathrm{kg}$ & $<300$ & $<300$ & $<300$ & $<100$ \\
\hline 1,6-Dimethlnaphthalene & $\mu \mathrm{g} / \mathrm{kg}$ & E44 & E63 & $<300$ & 47 \\
\hline 2,3,6-Trimethnaphthalene & $\mu \mathrm{g} / \mathrm{kg}$ & E50 & E61 & $<300$ & 75 \\
\hline 2,6-Dimethlnaphthalene & $\mu \mathrm{g} / \mathrm{kg}$ & E70 & E91 & E59 & 115 \\
\hline 2-Chloronaphthalene & $\mu \mathrm{g} / \mathrm{kg}$ & $<300$ & $<300$ & $<300$ & $<100$ \\
\hline 2-Ethylnaphthalene & $\mu \mathrm{g} / \mathrm{kg}$ & $<300$ & $<300$ & $<300$ & 48 \\
\hline Benzo[b]fluoranthene & $\mu \mathrm{g} / \mathrm{kg}$ & 700 & 1,800 & 570 & 1,850 \\
\hline Benz[ghi]perylene & $\mu \mathrm{g} / \mathrm{kg}$ & E230 & 590 & E220 & 845 \\
\hline Phenanthrene & $\mu \mathrm{g} / \mathrm{kg}$ & 700 & 2,500 & 390 & 1,650 \\
\hline 1-Methylphenanthrene & $\mu \mathrm{g} / \mathrm{kg}$ & E140 & $<300$ & E66 & 155 \\
\hline Benzo[def]fluorene & $\mu \mathrm{g} / \mathrm{kg}$ & E140 & 400 & E69 & 305 \\
\hline Acridine & $\mu \mathrm{g} / \mathrm{kg}$ & $<300$ & $\mathrm{E} 130$ & $<300$ & 100 \\
\hline
\end{tabular}


Table 10. Concentrations of mercury, carbon, and hydrophobic organic compounds in bed sediment, Meduxnekeag River, Maine, July 2003._Continued

$[\mu \mathrm{g} / \mathrm{kg}$, micrograms per kilogram; $\mu \mathrm{g} / \mathrm{g}$, micrograms per gram; $\mathrm{g} / \mathrm{kg}$, grams per kilogram; <, less than; $\mathrm{n}$, number of samples; E, estimated; --, no data; NECB NAWQA, New England Coastal Basins National Water-Quality Assessment]

\begin{tabular}{|c|c|c|c|c|c|}
\hline \multirow[b]{3}{*}{ Compound } & \multirow[b]{3}{*}{ Units } & \multicolumn{3}{|c|}{ Station identifier and sample date } & \multirow{3}{*}{$\begin{array}{l}\text { Median from } \\
\text { NECB } \\
\text { NAWOA } \\
\text { (n=14 for } \\
\text { organics and } \\
\text { carbon, } n=63 \\
\text { for mercury) }\end{array}$} \\
\hline & & $\begin{array}{l}01017970 \\
7 / 16 / 2003\end{array}$ & $\begin{array}{l}01018015 \\
7 / 17 / 2003\end{array}$ & $\begin{array}{l}01018035 \\
7 / 17 / 2003\end{array}$ & \\
\hline & & \multicolumn{3}{|c|}{ Concentration } & \\
\hline \multicolumn{6}{|c|}{ Phenols } \\
\hline Phenol & $\mu \mathrm{g} / \mathrm{kg}$ & $<300$ & $<300$ & $<300$ & 75 \\
\hline 3,5-Dimethylphenol & $\mu \mathrm{g} / \mathrm{kg}$ & $<300$ & $<300$ & $<300$ & $<100$ \\
\hline 4-Chloro-3-methylphenol & $\mu \mathrm{g} / \mathrm{kg}$ & $<300$ & $<300$ & $<300$ & $<100$ \\
\hline C8-Alkylphenol & $\mu \mathrm{g} / \mathrm{kg}$ & $<300$ & $<300$ & $<300$ & -- \\
\hline 2-Chlorophenol & $\mu \mathrm{g} / \mathrm{kg}$ & $<300$ & $<300$ & $<300$ & $<100$ \\
\hline p-Cresol & $\mu \mathrm{g} / \mathrm{kg}$ & E130 & E140 & E140 & 790 \\
\hline \multicolumn{6}{|c|}{ Other compounds } \\
\hline Polychlorinated biphenyls (PCBs) & $\mu \mathrm{g} / \mathrm{kg}$ & $<250$ & $<250$ & $<250$ & 155 \\
\hline Benzo[c]cinnoline & $\mu \mathrm{g} / \mathrm{kg}$ & $<300$ & $<300$ & $<300$ & $<100$ \\
\hline 2,4-Dinitrotoluene & $\mu \mathrm{g} / \mathrm{kg}$ & $<300$ & $<300$ & $<300$ & $<100$ \\
\hline 2,6-Dinitrotoluene & $\mu \mathrm{g} / \mathrm{kg}$ & $<300$ & $<300$ & $<300$ & $<100$ \\
\hline Isophorone & $\mu \mathrm{g} / \mathrm{kg}$ & $<300$ & $<300$ & $<300$ & $<100$ \\
\hline 2,2'-Biquinoline & $\mu \mathrm{g} / \mathrm{kg}$ & $<300$ & $<300$ & $<300$ & $<100$ \\
\hline Quinoline & $\mu \mathrm{g} / \mathrm{kg}$ & $<300$ & $<300$ & $<300$ & $<100$ \\
\hline Phenanthridine & $\mu \mathrm{g} / \mathrm{kg}$ & $<300$ & $<300$ & $<300$ & 99 \\
\hline Isoquinoline & $\mu \mathrm{g} / \mathrm{kg}$ & $<300$ & $<300$ & $<300$ & $<100$ \\
\hline 9,10-Anthraquinone & $\mu \mathrm{g} / \mathrm{kg}$ & E130 & 320 & E60 & 490 \\
\hline 2-Chloroethoxymethane & $\mu \mathrm{g} / \mathrm{kg}$ & $<300$ & $<300$ & $<300$ & $<100$ \\
\hline Nitrosodipropylamine & $\mu \mathrm{g} / \mathrm{kg}$ & $<300$ & $<300$ & $<300$ & 100 \\
\hline Nitrosodiphenylamine & $\mu \mathrm{g} / \mathrm{kg}$ & $<300$ & $<300$ & $<300$ & $<100$ \\
\hline 1,2,4-Trichlorobenzene & $\mu \mathrm{g} / \mathrm{kg}$ & $<300$ & $<300$ & $<300$ & $<100$ \\
\hline 1,2-Dichlorobenzene & $\mu \mathrm{g} / \mathrm{kg}$ & $<300$ & $<300$ & $<300$ & $<100$ \\
\hline 1,3-Dichlorobenzene & $\mu \mathrm{g} / \mathrm{kg}$ & $<300$ & $<300$ & $<300$ & $<100$ \\
\hline 1,4-Dichlorobenzene & $\mu \mathrm{g} / \mathrm{kg}$ & $<300$ & $<300$ & $<300$ & $<100$ \\
\hline Azobenzene & $\mu \mathrm{g} / \mathrm{kg}$ & $<300$ & $<300$ & $<300$ & $<100$ \\
\hline Nitrobenzene & $\mu \mathrm{g} / \mathrm{kg}$ & $<300$ & $<300$ & $<300$ & $<100$ \\
\hline Pentachloronitrobenzene & $\mu \mathrm{g} / \mathrm{kg}$ & $<300$ & $<300$ & $<300$ & $<100$ \\
\hline Carbazole & $\mu \mathrm{g} / \mathrm{kg}$ & E42 & E160 & E39 & 220 \\
\hline Dibenzothiophene & $\mu \mathrm{g} / \mathrm{kg}$ & E94 & E180 & E83 & 100 \\
\hline 4-Bromodiphenyl ether & $\mu \mathrm{g} / \mathrm{kg}$ & $<300$ & $<300$ & $<300$ & $<100$ \\
\hline 4-Chlorodiphenylether & $\mu \mathrm{g} / \mathrm{kg}$ & $<300$ & $<300$ & $<300$ & $<100$ \\
\hline 2-Chloroethylether & $\mu \mathrm{g} / \mathrm{kg}$ & $<300$ & $<300$ & $<300$ & $<100$ \\
\hline Pentachloroanisole & $\mu \mathrm{g} / \mathrm{kg}$ & $<5$ & $<5$ & $<5$ & $<2$ \\
\hline
\end{tabular}


PAHs-fluoranthene, pyrene, chrysene, phenanthrene, benzo(a)anthracene, benzo(a)pyrene, benzo(k)fluoranthene, and benzo(b)fluoranthene-were in the sample from Highland Avenue. PAHs are thought to be derived primarily from anthropogenic sources such as municipal incineration or other combustion processes, although some are manufactured directly and are used in dye and (or) plastics manufacturing (Smith and others, 1988). Some PAHs of low molecular weight, such as naphthalene and acenaphthene, are known to degrade rapidly, whereas other PAHs of high molecular weight, such as fluoranthene, chrysene, and anthracene, are resistant to biodegradation (Smith and others, 1988). PAHs have low solubilities and partition strongly to sediment organic matter. Larsen and others (1983) found concentrations of benzo(a)pyrene (maximum 805 $\mu \mathrm{g} / \mathrm{kg})$, benzo(k)fluoranthene $(193 \mu \mathrm{g} / \mathrm{kg})$, and acenaphthene $(1,150 \mu \mathrm{g} / \mathrm{kg})$ in samples from Casco Bay, Maine.

\section{Comparisons with Data from Other Studies}

The data collected during this study were compared with those of the New England Coastal Basins (NECB) National Water Quality Assessment (NAWQA) study. The NECB NAWQA collected water- and bed-sediment- quality data at nine fixed stations, eight in Massachusetts and one in Maine (Campo and others, 2003). NAWQA data from station 01049265 (Kennebec River at North Sidney, Maine) were used for in-state comparisons in this report, whereas data from station 01095220 (Stillwater River near Sterling, Mass.) were used for land-use comparisons because land use in the Stillwater River watershed (forestry and agriculture) is similar to that in the Meduxnekeag River watershed. All NECB NAWQA data are available on the World Wide Web at URL http://nh.water.usgs.gov/CurrentProjects/nawqa/sw.htm.

Low concentrations of suspended sediment in samples from Meduxnekeag River watershed were similar to those in samples from Stillwater and Kennebec Rivers, but high concentrations were not as great as those in samples from Stillwater and Kennebec Rivers (table 11). In samples from all three watersheds, however, highest concentrations of suspended sediment were measured in April, probably in relation to snowmelt runoff.

Summary statistics of nutrient concentrations in samples from the three rivers are in table 12. Phosphorus concentrations in samples from Kennebec River were higher than those in samples from Stillwater and Meduxnekeag Rivers. Nitrogen concentrations in samples from Kennebec and Stillwater Rivers were similar, whereas those in samples from Meduxnekeag River (total nitrogen) generally were higher than both.

The NECB NAWQA study collected 63 samples for mercury in bed sediment at 56 stations. Mercury concentrations were 0.01 to $3.11 \mu \mathrm{g} / \mathrm{g}$ and the median concentration was $0.12 \mu \mathrm{g} / \mathrm{g}$. Concentrations higher than $0.2 \mu \mathrm{g} / \mathrm{g}$, which was the maximum concentration detected in the Meduxnekeag River watershed during this study, were found in about one-third of the NAWQA samples (Campo and others, 2003).

The NECB NAWQA study also sampled for organic compounds in bed sediment at 14 stations. Four pesticides (p,p'-DDD, nonachlor, chlordane, and dieldrin), three phthalates, and phenol were found in bed sediments during the NAWQA study but were not found in bed-sediment samples during this study. Concentrations of $\mathrm{p}$-cresol detected during the NAWQA study were higher than those detected during this study, but concentrations of all other organic compounds were similar in both studies.

\section{Summary and Conclusions}

Seasonal problems have been documented with Meduxnekeag River and its tributaries, including high sediment loads during runoff events, occasional algal blooms, and increased phosphorus concentrations during low flow. In response to these problems, U.S. Geological Survey, in cooperation with the Houlton Band of Maliseet Indians, studied the quality of surface water and bed sediments in the Meduxnekeag River watershed, Maine in 2003. The primary purpose of the study was to investigate the source of nutrients that may contribute to algal blooms in Meduxnekeag River during summer months of low flow. Surface water and bed sediments were sampled for nutrients, hydrophobic organic compounds, total carbon, and mercury during the spring and summer of 2003. Nitrate $\left(\mathrm{NO}_{3}\right)$ and organic nitrogen were detected in stream-water samples at concentrations from 0.04 (estimated) to $0.50 \mathrm{mg} / \mathrm{L}$ (milligrams

Table 11. Range of suspended-sediment concentrations in samples from three New England rivers, 1998-2003. [Concentrations in milligrams per liter; $\mathrm{n}$, number of samples.]

\begin{tabular}{llll}
\hline River & $\begin{array}{l}\text { Range of suspended } \\
\text { sediments concentrations } \\
\text { in April }\end{array}$ & $\begin{array}{l}\text { Range of suspended } \\
\text { sediments concentrations in } \\
\text { June }\end{array}$ & $\begin{array}{l}\text { Range of suspended } \\
\text { sediments concentrations all } \\
\text { months }\end{array}$ \\
\hline Meduxnekeag River & $7-8(n=3)$ & $3-10(n=2)$ & $3-18(n=5)$ \\
Kennebec River & $3-63(n=3)$ & $1-4(n=2)$ & $1-63(n=28)$ \\
Stillwater River & $2-58(n=4)$ & $3-7(n=3)$ & $2-58(n=39)$ \\
\hline
\end{tabular}


Table 12. Summary of nutrient concentrations in samples from Stillwater River, Massachusetts, and Kennebec and Meduxnekeag Rivers, Maine, 1998-2003.

$[N$, nitrogen; $P$, phosphorus; $E$, estimated; $<$, less than; $\leq$, less than or equal to; $n$, number of samples. Data for the Stillwater and Kennebec Rivers were summarized from tables available on the Web at URL http://nh.water.usgs.gov/CurrentProjects/nawqa/sw.htm. All concentrations are in milligrams per liter.]

\begin{tabular}{|c|c|c|c|c|c|c|c|c|c|}
\hline Statistic & Ammonia & $\begin{array}{c}\text { Ammonia } \\
\text { + organic } \\
\mathbf{N}, \\
\text { dissolved }\end{array}$ & $\begin{array}{c}\text { Total } \\
\text { ammonia } \\
+\underset{N}{\text { organic }}\end{array}$ & $\begin{array}{l}\text { Nitrate + } \\
\text { nitrite, } \\
\text { dissolved }\end{array}$ & $\begin{array}{c}\text { Nitrite, } \\
\text { dissolved }\end{array}$ & Total N & $\begin{array}{c}\text { P, } \\
\text { dissolved }\end{array}$ & Ortho P & Total P \\
\hline \multicolumn{10}{|c|}{ Stillwater River, Massachusetts, station $01095220(\mathrm{n}=39)$} \\
\hline Median & 0.02 & 0.2 & 0.27 & 0.15 & 0.01 & 0.43 & 0.006 & 0.01 & 0.016 \\
\hline Minimum & $<.02$ & E.06 & E.06 & .06 & E.003 & .25 & E.003 & E.009 & E.005 \\
\hline Maximum & .053 & .38 & .53 & .31 & .02 & .64 & .05 & .02 & .145 \\
\hline \multicolumn{10}{|c|}{ Kennebec River, Maine, station $010149265(\mathrm{n}=24)$} \\
\hline Median & 0.02 & 0.24 & 0.29 & 0.12 & $<0.01$ & 0.41 & 0.026 & 0.021 & 0.036 \\
\hline Minimum & $<.02$ & $<.1$ & $<.1$ & .06 & $<.01$ & .25 & .006 & $<.01$ & .019 \\
\hline Maximum & .14 & .34 & .38 & .16 & .02 & .55 & .06 & .054 & .077 \\
\hline \multicolumn{10}{|c|}{ Meduxnekeag River, Maine, several stations $(9 \leq \mathrm{n} \leq 26)$} \\
\hline Median & $<0.04$ & $<0.008$ & 0.31 & 0.18 & $<0.008$ & 0.54 & 0.008 & $<0.02$ & $<0.04$ \\
\hline Minimum & $<.04$ & $<.008$ & .23 & .04 & $<.008$ & .38 & .003 & $<.02$ & $<.04$ \\
\hline Maximum & $<.04$ & $<.008$ & .62 & .50 & $<.008$ & .75 & $<.04$ & $<.02$ & $<.04$ \\
\hline
\end{tabular}

per liter) and from 0.19 to $0.62 \mathrm{mg} / \mathrm{L}$, respectively. Organic nitrogen contributed more than half of the total nitrogen in most of the samples. Median concentrations of total nitrogen from all sampling events were higher in samples from downstream stations than from upstream stations. Concentrations of dissolved phosphorus were from 0.003 (estimated) to 0.012 $\mathrm{mg} / \mathrm{L}$, with highest concentrations in samples from South Branch and the station furthest downstream, Meduxnekeag River at Lowery Road (01018035). Peak concentrations of phosphorus were observed for all stations on July 24 during low flow.

Total instantaneous phosphorus load during high flow (April 23-24) was estimated to be $211 \mathrm{~kg} / \mathrm{d}$ (kilograms per day) at Lowery Road, of which 89 percent was in water and 11 percent bound to suspended sediment. At the B Stream (01018010), South Branch (01017980), and Porter Settlement Road (01017970) stations, total instantaneous phosphorus loads were from 43 to $71 \mathrm{~kg} / \mathrm{d}$, of which 86 to 93 percent were in water.

Drainage areas of B Stream, South Branch, and Meduxnekeag River above Porter Settlement Road include 86 percent of the drainage area at Lowery Road; however, loads of total, organic, and NO3 nitrogen at those stations on June 2-3 were equal to only 68,67 , and 70 percent of the total, organic, and NO3 nitrogen loads, respectively, observed at Lowery Road. These and other data indicate that the part of the watershed that includes Houlton and several small urban brooks contributed high concentrations of nitrate to Meduxnekeag River during the high flows on April 23-24 and high concentrations of both organic and nitrate nitrogen on June 2-3. On a per unit area basis, B Stream contributed more organic nitrogen to Medux- nekeag River at Lowery Road than either South Branch or Meduxnekeag River above Porter Settlement Road.

Samples of bed sediments from nine stations along the river were analyzed for phosphorus; concentrations were from 180 to $660 \mathrm{mg} / \mathrm{kg}$ (milligrams per kilogram), with highest concentrations in samples from small tributaries to Meduxnekeag River. In comparison with data from studies in Massachusetts, the observed concentrations of phosphorus from the Meduxnekeag River watershed during this study were low. These low concentrations of phosphorus, combined with high concentrations of dissolved oxygen observed throughout the study, restricted release of phosphorus from sediments during 2003. No large algal blooms were observed in the study area during 2003, but a cause-and-effect relation between the impedance of phosphorus release from bed sediments and the lack of large algal blooms could not be established from the data.

Samples of bed sediment from three main-stem stations were analyzed for hydrophobic organic compounds, mercury, and total organic and inorganic carbon. Concentrations of mercury ranged from 0.06 to $0.2 \mu \mathrm{g} / \mathrm{g}$ (micrograms per gram). Bed-sediment samples from the three stations did not contain detectable concentrations of polychlorinated biphenyls (PCBs) or phthalates. The only phenolic compound detected was pcresol. Metabolites of the pesticide DDT were detected in two of the three samples in concentrations as high as $13 \mu \mathrm{g} / \mathrm{kg}$. Highest concentrations of polycyclic aromatic hydrocarbons were in the sample from Meduxnekeag River at Highland Avenue in Houlton (01018015).

Results of this study in the Meduxnekeag River watershed were compared to those of the New England Coastal 
Basins study of the National Water-Quality Assessment (NECB NAWQA). Phosphorus concentrations in samples from Meduxnekeag River were lower than those in samples from Kennebec River, Maine, but similar to those in samples from Stillwater River, Massachusetts. Nitrogen concentrations, however, generally were higher in samples from Meduxnekeag River than those in samples from Kennebec and Stillwater Rivers. About one-third of the concentrations of mercury in bed-sediment samples collected during the NECB NAWQA were higher than $0.2 \mu \mathrm{g} / \mathrm{g}$, which was the maximum concentration detected during this study. Four pesticides, three phthalates, and phenol were found in bed-sediment samples during the NECB NAWQA study but were not found in bed-sediment samples during this study. Concentrations of most organic compounds found in both studies were similar.

Although a goal of the study was to relate the quality of the river to the presence of algal blooms, no large algal blooms were observed in the study area during spring and summer 2003. Concentrations of phosphorus in surface waters of Meduxnekeag River were lower than those detected in the NECB NAWQA study. It may be that the algae growth was less in 2003 than that observed in previous years because phosphorus concentrations were relatively low.

\section{Acknowledgments}

Our thanks go to Cara Ellis and David Joseph of HBMI, who sampled streams during the course of the study. Their assistance alleviated the necessity of many field trips by USGS personnel to the study area.

\section{References Cited}

Aroostook Water and Soil Management Board, 1996, How to deal with low flow periods and irrigating farmer's and environmental concerns in Aroostook County: Presque Isle, Maine, Aroostook Water and Soil Management Program 8 p.

Breault, R.F., Reisig, K.R., Barlow, L.K., and Weiskel, P.K., 2000, Distribution and potential for adverse biological effects of inorganic elements and organic compounds in bottom sediment, lower Charles River, Massachusetts: U.S. Geological Survey Water-Resources Investigations Report 00-4180, $70 \mathrm{p}$.

Breault, R.F., Cooke, M.G., and Merrill, M., 2004, Sediment quality and polychlorinated biphenyls in the lower Neponset River, Massachusetts, and implications for urban river restoration: U.S. Geological Survey Scientific Investigations Report 2004-5109, 48 p.
Campo, K.W., Flanagan, S.M., and Robinson, K.W., 2003, Water quality of selected rivers in the New England Coastal Basins in Maine, Massachusetts, New Hampshire, and Rhode Island, 1998-2000: U.S. Geological Survey Water-Resources Investigations Report 03-4210, 43 p.

Dudley, R.W., 2004, Estimating monthly, annual, and low 7 day, 10-year streamflows for ungaged rivers in Maine: U.S. Geological Survey Scientific Investigations Report 2004-5026, 22 p.

Hem, J.D., 1992, Study and interpretation of the chemical characteristics of natural water (3d edition): U.S. Geological Survey Water-Supply Paper 2254, $263 \mathrm{p}$.

Hillel, D., 1982, Introduction to soil physics: San Diego, Calif., Academic Press, 364 p.

Hornung, R.W. and Reed, L.D., 1990, Estimation of average concentration in the presence of nondetectable values: Applied Occupational and Environmental Hygiene, v. 5, p. 46-51.

Houlton Water Company, 2004, The Houlton Water Company water system: Houlton, Maine, available online at URL http://www.ainop.com/hwco/water_system.htm, accessed March 3, 2004.

Kaushal, S.S., and Lewis Jr., W. M., 2003, Patterns in the chemical fractionation of organic nitrogen in Rocky Mountain streams: Ecosystems, no. 6, p. 483-492.

Larsen, P.F., Gadbois, D.F., Johnson, A.C., and Doggett, L.F., 1983, Distribution of polycyclic aromatic hydrocarbons in the surficial sediments of Casco Bay, Maine: Bulletin of Environmental Contamination and Toxicology, v. 30, p. 530-535.

Maine Department of Environmental Protection, 1998a, Maine Section 303(d) waters--1998: available online at URL http://www.state.me.gov/dep/blwq/docmonitoring/303d981.pdf, accessed February 5, 2004.

Maine Department of Environmental Protection, 1998b, State of Maine unified watershed assessment: available online at URL http://www.maine.gov/dep/blwq/docwatershed/uwacate2.pdf, accessed March 8, 2004.

Maine Department of Environmental Protection, 2000, Meduxnekeag River TMDL Final: available online at URL http://www.state.me.us/dep/blwq/docmonitoring/tmdlmedrep.pdf, accessed September 3, 2003.

Maine Department of Environmental Protection, 2002, Integrated water quality and monitoring assessment report: available online at URL

http://www.maine.gov/dep/blwq/2002Appendix.pdf, accessed March 8, 2004.

Maine Department of Environmental Protection, 2003, Status of Licensed Discharges: available online at URL http://www.maine.gov/dep/blwq/report/statuslicenseddis charge03.pdf, accessed February 5, 2004. 
Maine Department of Inland Fisheries and Wildlife, 2003, State of Maine 2003-2004 Ice Fishing Regulations: Augusta, Maine, available online at URL http://www.maine.gov/ifw/fishing/icefishinglaws20032004.htm, accessed March 3, 2004.

Meybeck, Michel, 1982, Concentrations des eaux fluviales en elements majeurs et apports en solution aux oceans: Revue de Geologie Dynamique et de Geographie Physique [Paris], v. 21, pt. 3, p. 215-246.

National Climatic Data Center, 1999, U.S. monthly precipitation: available online at URL http://lwf.ncdc.noaa.gov/oa/climate/online/coop-precip.html\#INTRO, accessed March 3, 2004.

Oliver, R.L., Hart, B.T., Olley, J., Grace, M., Rees, C, and Caitcheon, G., 1999, The Darling River: algal growth and the cycling and sources of nutrients: Canberra, Australia, Murray-Darling Basin Commission, variously paginated.

Patton, C.J., and Truitt, E.P., 1992, Methods of analysis by the U.S. Geological Survey National Water Quality Laboratory--Determination of total phosphorus by a Kjeldahl digestion method and an automated colorimetric finish that includes dialysis: U.S. Geological Survey Open-File Report 92-146, 39 p.

Patton, C.J., and Truitt, E.P., 2000, Methods of analysis by the U.S. Geological Survey National Water Quality Laboratory--Determination of ammonium plus organic nitrogen by a Kjeldahl digestion method and an automated photometric finish that includes digest cleanup by gas diffusion: U.S. Geological Survey Open-File Report 00-170, $31 \mathrm{p}$.

Prescott Jr, G.C., 1971, Records of selected wells and test holes in part of the Meduxnekeag River and Prestile Stream drainage basins: U.S. Geological Survey Maine Basic Data Report, no. 7, Ground-Water Series, 17 p.

Shelton, L.R. and Capel, P.D., 1994, Guidelines for collecting and processing samples of stream bed sediment for analysis of trace elements and organic contaminants for the National Water-Quality Assessment program: U.S. Geological Survey Open-File Report 94-458, 20 p.
Smith, J.A., Witkowski, P.J., and Fusillo, T.V., 1988, Manmade organic compounds in the surface waters of the United States--A review of current understanding: U.S. Geological Survey Circular 1007, 92 p.

Southern Aroostook County Soil and Water Conservation District, 1993, Watershed protection plan/environmental assessment, main branch Meduxnekeag River watershed, Aroostook County, Maine: Houlton, Maine, 86 p.

Thompson, W.B., and Borns, H.W., eds., Surficial geologic map of Maine: Maine Geological Survey, Department of Conservation, 1 pl., 1:500,000 scale.

Town of Houlton, 2004, Regional economic development and strategic marketing plan: Houlton, Maine, Jim Damicis Associates, $93 \mathrm{p}$.

U.S. Department of Agriculture, 1994, State soil geographic (STATSGO) data base, data use information: Fort Worth, Texas, National Soil Survey Center Miscellaneous Publication 1492, 39 p., appendixes.

U.S. Environmental Protection Agency, 2004, List of drinking water contaminants and MCLs: available online at URL http://www.epa.gov/safewater/mcl.html, accessed April 5, 2004.

U.S. Geological Survey, 1999, The quality of our Nation's waters--Nutrients and pesticides: U.S. Geological Survey Circular 1225, 82 p.

U.S Geological Survey, variously dated, National field manual for the collection of water-quality data: U.S. Geological Survey Techniques of Water-Resources Investigations, book 9, chaps. A1-A9, available online at http://pubs.water.usgs.gov/twri9A. [Chapter updates and revisions are ongoing and are summarized at http://water.usgs.gov/owq/FieldManual/mastererrata.html] 

Appendix 1. Historical streamflow, temperature, and specific conductance at station 01018000, Meduxnekeag River near Houlton, Maine 
26 Nutrients, Organic Compounds, and Mercury in the Meduxnekeag River Watershed, Maine, 2003

Table 1. Historical streamflow, temperature, and specific conductance at station 01018000, Meduxnekeag River near Houlton, Maine

$\left[{ }^{\circ} \mathrm{C}\right.$, Celsius; --, no data]

\begin{tabular}{|c|c|c|c|c|}
\hline Date & $\begin{array}{l}\text { Instantaneous } \\
\text { streamflow, in } \\
\text { cubic feet per } \\
\text { second }\end{array}$ & $\begin{array}{c}\text { Water } \\
\text { temperature, in } \\
{ }^{\circ} \mathrm{C}\end{array}$ & $\begin{array}{c}\text { Air temperature, } \\
\text { in }{ }^{\circ} \mathrm{C}\end{array}$ & $\begin{array}{c}\text { Specific } \\
\text { conductance, in } \\
\text { microsiemens per } \\
\text { centimeter at } 25{ }^{\circ} \mathrm{C}\end{array}$ \\
\hline $10 / 04 / 1976$ & -- & 11 & 16 & 148 \\
\hline $11 / 16 / 1976$ & -- & 0 & -1.5 & 119 \\
\hline $12 / 14 / 1976$ & -- & 0 & -17 & 89 \\
\hline 01/17/1977 & -- & 0 & 13 & 94 \\
\hline 02/22/1977 & -- & 0 & -6 & 198 \\
\hline 04/11/1977 & -- & 0 & 4 & 139 \\
\hline 04/23/1977 & -- & 2 & 11 & 169 \\
\hline 05/31/1977 & -- & 17 & 22 & 143 \\
\hline 07/18/1977 & -- & 20 & 24 & 120 \\
\hline 08/22/1977 & -- & 16 & 20 & 180 \\
\hline 09/26/1977 & -- & 14 & 14 & 170 \\
\hline $10 / 06 / 1977$ & 486 & 9.5 & -- & 102 \\
\hline 11/07/1977 & 234 & 7 & -- & 148 \\
\hline $10 / 10 / 1978$ & 19 & 8.5 & 13 & 162 \\
\hline $11 / 14 / 1978$ & 31 & 2 & 6 & 168 \\
\hline $12 / 18 / 1978$ & 39 & 0 & -4 & 125 \\
\hline 01/29/1979 & 423 & .5 & 2 & 143 \\
\hline $02 / 26 / 1979$ & 122 & 0 & -4 & 180 \\
\hline 03/26/1979 & 5,590 & 1 & 5 & 64 \\
\hline 05/01/1979 & 1,950 & 7.5 & 12 & 68 \\
\hline 06/25/1979 & 183 & 16.5 & 14.5 & 140 \\
\hline 09/18/1979 & 136 & 16 & 18.5 & 125 \\
\hline $10 / 23 / 1979$ & 151 & 12 & 17 & 144 \\
\hline $12 / 11 / 1979$ & 158 & 0 & -4 & 140 \\
\hline $01 / 28 / 1980$ & 66 & 0 & -6.5 & 170 \\
\hline 02/25/1980 & 25 & 0 & 9 & 185 \\
\hline $07 / 15 / 1980$ & 144 & 19 & 27 & 130 \\
\hline 08/15/1980 & 124 & 19 & 21 & 130 \\
\hline 10/07/1980 & 296 & 9 & 8 & 125 \\
\hline $11 / 13 / 1980$ & 415 & 2 & 2 & 135 \\
\hline $12 / 16 / 1980$ & 330 & 0 & -20 & 86 \\
\hline 02/02/1981 & 82 & 0 & 5.5 & 90 \\
\hline 03/20/1981 & 195 & 0 & 2 & 175 \\
\hline 04/08/1981 & 1820 & 2 & 10 & 100 \\
\hline 02/09/1982 & 191 & 0 & -5 & 120 \\
\hline 03/29/1982 & 470 & 0 & 2 & 135 \\
\hline 05/06/1982 & 636 & 10.5 & 13 & 92 \\
\hline 06/09/1982 & 75 & 18 & 19 & 134 \\
\hline 07/30/1982 & 71 & 19 & 18 & 160 \\
\hline
\end{tabular}




\section{Appendix 2. Analytical schedules and detection limits}


Table 2A. Constituents in bed-sediment analysis, U.S. Geological Survey National WaterQuality Laboratory Schedule 2500.

[CAS, Chemical Abstracts Service; RL, reporting limit; $\mu \mathrm{g} / \mathrm{kg}$, micrograms per kilogram; g/kg, grams per kilogram; --, not applicable]

\begin{tabular}{|c|c|c|c|c|}
\hline Constituent & Parameter code & CAS number & $\mathbf{R L}$ & Units \\
\hline alpha-HCH & 49338 & $319-84-6$ & 1 & $\mu \mathrm{g} / \mathrm{kg}$ \\
\hline beta-HCH & 49339 & $319-85-7$ & 1 & $\mu \mathrm{g} / \mathrm{kg}$ \\
\hline Dibenz[a,h]anthracene & 49461 & $53-70-3$ & 50 & $\mu \mathrm{g} / \mathrm{kg}$ \\
\hline Chrysene & 49450 & $218-01-9$ & 50 & $\mu \mathrm{g} / \mathrm{kg}$ \\
\hline 2-Methylanthracene & 49435 & $613-12-7$ & 50 & $\mu \mathrm{g} / \mathrm{kg}$ \\
\hline 3,5-Dimethylphenol & 49421 & $108-68-9$ & 50 & $\mu \mathrm{g} / \mathrm{kg}$ \\
\hline 4H-cyclopenta[def]phenanthrene & 49411 & $203-64-5$ & 50 & $\mu \mathrm{g} / \mathrm{kg}$ \\
\hline 4,6-Dinitro-2-methylphenol & 49419 & $534-52-1$ & 50 & $\mu \mathrm{g} / \mathrm{kg}$ \\
\hline 4-Bromodiphenyl ether & 49454 & $101-55-3$ & 50 & $\mu \mathrm{g} / \mathrm{kg}$ \\
\hline 4-Chlorodiphenyl ether & 49455 & $7005-72-3$ & 50 & $\mu \mathrm{g} / \mathrm{kg}$ \\
\hline Anthraquinone & 49437 & $84-65-1$ & 50 & $\mu \mathrm{g} / \mathrm{kg}$ \\
\hline Fluorene & 49399 & $86-73-7$ & 50 & $\mu \mathrm{g} / \mathrm{kg}$ \\
\hline 1-Methyl-9H-fluorene & 49398 & $1730-37-6$ & 50 & $\mu \mathrm{g} / \mathrm{kg}$ \\
\hline Acenaphthene & 49429 & $83-32-9$ & 50 & $\mu \mathrm{g} / \mathrm{kg}$ \\
\hline Acenaphthylene & 49428 & $208-96-8$ & 50 & $\mu \mathrm{g} / \mathrm{kg}$ \\
\hline Acridine & 49430 & $260-94-6$ & 50 & $\mu \mathrm{g} / \mathrm{kg}$ \\
\hline Aldrin & 49319 & $309-00-2$ & 1 & $\mu \mathrm{g} / \mathrm{kg}$ \\
\hline Pentachloroanisole & 49460 & $1825-21-4$ & 5 & $\mu \mathrm{g} / \mathrm{kg}$ \\
\hline Anthracene & 49434 & $120-12-7$ & 50 & $\mu \mathrm{g} / \mathrm{kg}$ \\
\hline Azobenzene & 49443 & $103-33-3$ & 50 & $\mu \mathrm{g} / \mathrm{kg}$ \\
\hline Benz[a]anthracene & 49436 & $56-55-3$ & 50 & $\mu \mathrm{g} / \mathrm{kg}$ \\
\hline 1,2,4-Trichlorobenzene & 49438 & $120-82-1$ & 50 & $\mu \mathrm{g} / \mathrm{kg}$ \\
\hline Hexachlorobenzene & 49343 & $118-74-1$ & 5 & $\mu \mathrm{g} / \mathrm{kg}$ \\
\hline 1,3-Dichlorobenzene & 49441 & $541-73-1$ & 50 & $\mu \mathrm{g} / \mathrm{kg}$ \\
\hline Nitrobenzene & 49444 & $98-95-3$ & 50 & $\mu \mathrm{g} / \mathrm{kg}$ \\
\hline 1,2-Dichlorobenzene & 49439 & $95-50-1$ & 50 & $\mu \mathrm{g} / \mathrm{kg}$ \\
\hline 1,4-Dichlorobenzene & 49442 & $106-46-7$ & 50 & $\mu \mathrm{g} / \mathrm{kg}$ \\
\hline Pentachloronitrobenzene & 49446 & $82-68-8$ & 50 & $\mu \mathrm{g} / \mathrm{kg}$ \\
\hline Benzo[a]pyrene & 49389 & $50-32-8$ & 50 & $\mu \mathrm{g} / \mathrm{kg}$ \\
\hline Benzo[b]fluoranthene & 49458 & $205-99-2$ & 50 & $\mu \mathrm{g} / \mathrm{kg}$ \\
\hline Benzo[ghi]perylene & 49408 & $191-24-2$ & 50 & $\mu \mathrm{g} / \mathrm{kg}$ \\
\hline Benzo[k]fluoranthene & 49397 & $207-08-9$ & 50 & $\mu \mathrm{g} / \mathrm{kg}$ \\
\hline Benzo[c]cinnoline & 49468 & $230-17-1$ & 50 & $\mu \mathrm{g} / \mathrm{kg}$ \\
\hline 2,2'-Biquinoline & 49391 & $119-91-5$ & 50 & $\mu \mathrm{g} / \mathrm{kg}$ \\
\hline bis(2-Chloroisopropyl) ether & 49457 & $108-60-1$ & 50 & $\mu \mathrm{g} / \mathrm{kg}$ \\
\hline bis(2-Chloroethyl)ether & 49456 & $111-44-4$ & 50 & $\mu \mathrm{g} / \mathrm{kg}$ \\
\hline Hexachlorobutadiene & 49448 & $87-68-3$ & 50 & $\mu \mathrm{g} / \mathrm{kg}$ \\
\hline Carbazole & 49449 & $86-74-8$ & 50 & $\mu \mathrm{g} / \mathrm{kg}$ \\
\hline Chloroneb & 49322 & $2675-77-6$ & 5 & $\mu \mathrm{g} / \mathrm{kg}$ \\
\hline cis-Chlordane & 49320 & $5103-71-9$ & 1 & $\mu \mathrm{g} / \mathrm{kg}$ \\
\hline cis-Nonachlor & 49316 & 5103-73-1 & 1 & $\mu \mathrm{g} / \mathrm{kg}$ \\
\hline cis-Permethrin & 49349 & $54774-45-7$ & 5 & $\mu \mathrm{g} / \mathrm{kg}$ \\
\hline Hexachlorocyclopentadiene & 49489 & $77-47-4$ & 50 & $\mu \mathrm{g} / \mathrm{kg}$ \\
\hline Dacthal & 49324 & $1861-32-1$ & 5 & $\mu \mathrm{g} / \mathrm{kg}$ \\
\hline N-Nitrosodi-n-propylamine & 49431 & $621-64-7$ & 50 & $\mu \mathrm{g} / \mathrm{kg}$ \\
\hline
\end{tabular}


Table 2A. Constituents in bed-sediment analysis, U.S. Geological Survey National Water-

Quality Laboratory Schedule 2500.-Continued

[CAS, Chemical Abstracts Service; RL, reporting limit; $\mu \mathrm{g} / \mathrm{kg}$, micrograms per kilogram; g/kg, grams per kilogram;

--, not applicable]

\begin{tabular}{|c|c|c|c|c|}
\hline Constituent & Parameter code & CAS number & $\mathbf{R L}$ & Units \\
\hline Dieldrin & 49331 & $60-57-1$ & 1 & $\mu \mathrm{g} / \mathrm{kg}$ \\
\hline N-Nitrosodiphenylamine & 49433 & $86-30-6$ & 50 & $\mu \mathrm{g} / \mathrm{kg}$ \\
\hline alpha-Endosulfan & 49332 & $959-98-8$ & 1 & $\mu \mathrm{g} / \mathrm{kg}$ \\
\hline Endrin & 49335 & $72-20-8$ & 2 & $\mu \mathrm{g} / \mathrm{kg}$ \\
\hline Hexachloroethane & 49453 & $67-72-1$ & 50 & $\mu \mathrm{g} / \mathrm{kg}$ \\
\hline Fluoranthene & 49466 & $206-44-0$ & 50 & $\mu \mathrm{g} / \mathrm{kg}$ \\
\hline Heptachlor & 49341 & $76-44-8$ & 1 & $\mu \mathrm{g} / \mathrm{kg}$ \\
\hline Heptachlor epoxide & 49342 & $1024-57-3$ & 1 & $\mu \mathrm{g} / \mathrm{kg}$ \\
\hline Indeno[1,2,3-cd]pyrene & 49390 & $193-39-5$ & 50 & $\mu \mathrm{g} / \mathrm{kg}$ \\
\hline Isodrin & 49344 & $465-73-6$ & 1 & $\mu \mathrm{g} / \mathrm{kg}$ \\
\hline Isophorone & 49400 & $78-59-1$ & 50 & $\mu \mathrm{g} / \mathrm{kg}$ \\
\hline Isoquinoline & 49394 & $119-65-3$ & 50 & $\mu \mathrm{g} / \mathrm{kg}$ \\
\hline Lindane & 49345 & $58-89-9$ & 1 & $\mu \mathrm{g} / \mathrm{kg}$ \\
\hline 4-Chloro-3-methylphenol & 49422 & $59-50-7$ & 50 & $\mu \mathrm{g} / \mathrm{kg}$ \\
\hline 2,4,6-Trimethylphenol & 49416 & $527-60-6$ & 50 & $\mu \mathrm{g} / \mathrm{kg}$ \\
\hline bis(2-Chloroethoxy)methane & 49401 & $111-91-1$ & 50 & $\mu \mathrm{g} / \mathrm{kg}$ \\
\hline o,p'-Methoxychlor & 49347 & $30667-99-3$ & 5 & $\mu \mathrm{g} / \mathrm{kg}$ \\
\hline p,p'-Methoxychlor & 49346 & $72-43-5$ & 5 & $\mu \mathrm{g} / \mathrm{kg}$ \\
\hline Mirex & 49348 & $2385-85-5$ & 1 & $\mu \mathrm{g} / \mathrm{kg}$ \\
\hline Naphthalene & 49402 & $91-20-3$ & 50 & $\mu \mathrm{g} / \mathrm{kg}$ \\
\hline 1,2-Dimethylnaphthalene & 49403 & $573-98-8$ & 50 & $\mu \mathrm{g} / \mathrm{kg}$ \\
\hline 1,6-Dimethylnaphthalene & 49404 & $575-43-9$ & 50 & $\mu \mathrm{g} / \mathrm{kg}$ \\
\hline 2,3,6-Trimethylnaphthalene & 49405 & $829-26-5$ & 50 & $\mu \mathrm{g} / \mathrm{kg}$ \\
\hline 2,6-Dimethylnaphthalene & 49406 & $581-42-0$ & 50 & $\mu \mathrm{g} / \mathrm{kg}$ \\
\hline 2-Chloronaphthalene & 49407 & $91-58-7$ & 50 & $\mu \mathrm{g} / \mathrm{kg}$ \\
\hline 2-Ethylnaphthalene & 49948 & $939-27-5$ & 50 & $\mu \mathrm{g} / \mathrm{kg}$ \\
\hline$o, p^{\prime}-\mathrm{DDD}$ & 49325 & $53-19-0$ & 1 & $\mu \mathrm{g} / \mathrm{kg}$ \\
\hline o,p'-DDE & 49327 & $3424-82-6$ & 1 & $\mu \mathrm{g} / \mathrm{kg}$ \\
\hline$o, p^{\prime}-\mathrm{DDT}$ & 49329 & $789-02-6$ & 2 & $\mu \mathrm{g} / \mathrm{kg}$ \\
\hline Oxychlordane & 49318 & $27304-13-8$ & 1 & $\mu \mathrm{g} / \mathrm{kg}$ \\
\hline $\mathrm{p}, \mathrm{p}^{\prime}-\mathrm{DDD}$ & 49326 & $72-54-8$ & 1 & $\mu \mathrm{g} / \mathrm{kg}$ \\
\hline $\mathrm{p}, \mathrm{p}^{\prime}-\mathrm{DDE}$ & 49328 & $72-55-9$ & 1 & $\mu \mathrm{g} / \mathrm{kg}$ \\
\hline $\mathrm{p}, \mathrm{p}^{\prime}-\mathrm{DDT}$ & 49330 & $50-29-3$ & 2 & $\mu \mathrm{g} / \mathrm{kg}$ \\
\hline p-Cresol & 49451 & $106-44-5$ & 50 & $\mu \mathrm{g} / \mathrm{kg}$ \\
\hline Polychlorinated biphenyls & 49459 & $1336-36-3$ & 50 & $\mu \mathrm{g} / \mathrm{kg}$ \\
\hline Phenanthrene & 49409 & $85-01-8$ & 50 & $\mu \mathrm{g} / \mathrm{kg}$ \\
\hline 1-Methylphenanthrene & 49410 & $832-69-9$ & 50 & $\mu \mathrm{g} / \mathrm{kg}$ \\
\hline Phenanthridine & 49393 & $229-87-8$ & 50 & $\mu \mathrm{g} / \mathrm{kg}$ \\
\hline Phenol & 49413 & $108-95-2$ & 50 & $\mu \mathrm{g} / \mathrm{kg}$ \\
\hline 2,4,6-Trichlorophenol & 49415 & $88-06-2$ & 50 & $\mu \mathrm{g} / \mathrm{kg}$ \\
\hline 2,4-Dichlorophenol & 49417 & $120-83-2$ & 50 & $\mu \mathrm{g} / \mathrm{kg}$ \\
\hline 2,4-Dinitrophenol & 49418 & $51-28-5$ & 50 & $\mu \mathrm{g} / \mathrm{kg}$ \\
\hline C8-Alkylphenol & 49424 & -- & 50 & $\mu \mathrm{g} / \mathrm{kg}$ \\
\hline 2-Chlorophenol & 49467 & $95-57-8$ & 50 & $\mu \mathrm{g} / \mathrm{kg}$ \\
\hline 2-Nitrophenol & 49420 & $88-75-5$ & 50 & $\mu \mathrm{g} / \mathrm{kg}$ \\
\hline 4-Nitrophenol & 49423 & $100-02-7$ & 50 & $\mu \mathrm{g} / \mathrm{kg}$ \\
\hline Pentachlorophenol & 49425 & $87-86-5$ & 50 & $\mu \mathrm{g} / \mathrm{kg}$ \\
\hline
\end{tabular}


Table 2A. Constituents in bed-sediment analysis, U.S. Geological Survey National WaterQuality Laboratory Schedule 2500.-Continued

[CAS, Chemical Abstracts Service; RL, reporting limit; $\mu \mathrm{g} / \mathrm{kg}$, micrograms per kilogram; g/kg, grams per kilogram; ,-- not applicable]

\begin{tabular}{lllrc}
\hline Constituent & Parameter code & CAS number & RL & Units \\
\hline bis(2-Ethylhexyl) phthalate & 49426 & $117-81-7$ & 50 & $\mu \mathrm{g} / \mathrm{kg}$ \\
Butylbenzyl phthalate & 49427 & $85-68-7$ & 50 & $\mu \mathrm{g} / \mathrm{kg}$ \\
Di-n-butyl phthalate & 49381 & $84-74-2$ & 50 & $\mu \mathrm{g} / \mathrm{kg}$ \\
Diethyl phthalate & 49383 & $84-66-2$ & 50 & $\mu \mathrm{g} / \mathrm{kg}$ \\
Dimethyl phthalate & 49384 & $131-11-3$ & 50 & $\mu \mathrm{g} / \mathrm{kg}$ \\
Di-n-octyl phthalate & 49382 & $117-84-0$ & 50 & $\mu \mathrm{g} / \mathrm{kg}$ \\
Pyrene & 49387 & $129-00-0$ & 50 & $\mu \mathrm{g} / \mathrm{kg}$ \\
1-Methylpyrene & 49388 & $2381-21-7$ & 50 & $\mu \mathrm{g} / \mathrm{kg}$ \\
Quinoline & 49392 & $91-22-5$ & 50 & $\mu \mathrm{g} / \mathrm{kg}$ \\
Dibenzothiophene & 49452 & $132-65-0$ & 50 & $\mu \mathrm{g} / \mathrm{kg}$ \\
2,4-Dinitrotoluene & 49395 & $121-14-2$ & 50 & $\mu \mathrm{g} / \mathrm{kg}$ \\
2,6-Dinitrotoluene & 49396 & $606-20-2$ & 50 & $\mu \mathrm{g} / \mathrm{kg}$ \\
Toxaphene & 49351 & $8001-35-2$ & 200 & $\mu \mathrm{g} / \mathrm{kg}$ \\
trans-Chlordane & 49321 & $5103-74-2$ & 1 & $\mu \mathrm{g} / \mathrm{kg}$ \\
trans-Nonachlor & 49317 & $39765-80-5$ & 1 & $\mu \mathrm{g} / \mathrm{kg}$ \\
trans-Permethrin & 49350 & $51877-74-8$ & 5 & $\mu \mathrm{gg} / \mathrm{kg}$ \\
Inorganic carbon & 49270 & -- & 0.2 & $\mathrm{~g} / \mathrm{kg}$ \\
Total carbon & 49272 & -- & 0.1 & $\mathrm{~g} / \mathrm{kg}$ \\
\hline
\end{tabular}

Table 2B. Constituents in bed-sediment analysis, U.S. Geological Survey National WaterQuality Laboratory Lab Code 1184.

[CAS, Chemical Abstracts Service; RL, reporting limit; $\mathrm{mg} / \mathrm{kg}$, milligrams per kilogram]

\begin{tabular}{lllll}
\hline Constituent & Parameter code & CAS number & RL & Units \\
\hline Phosphorus & 00668 & $7723-14-0$ & 40 & $\mathrm{mg} / \mathrm{kg}$ \\
\hline
\end{tabular}

Table 2C. Constituents in bed-sediment analysis, U.S. Geological Survey National WaterQuality Laboratory Lab Code 1453.

[CAS, Chemical Abstracts Service; RL, reporting limit; $\mu \mathrm{g} / \mathrm{g}$, micrograms per gram]

\begin{tabular}{lllll}
\hline Constituent & Parameter code & CAS number & RL & Units \\
\hline Mercury & 34912 & $7439-97-6$ & 0.02 & $\mu \mathrm{g} / \mathrm{g}$ \\
\hline
\end{tabular}


Table 2D. Constituents in surface-water analysis, U.S. Geological Survey National Water-Quality Laboratory Schedule 86.

[CAS, Chemical Abstracts Service; RL, reporting limit; mg/L, milligrams per liter; --, not applicable]

\begin{tabular}{lllcl}
\hline Constituent & Parameter code & CAS number & RL & Units \\
\hline Nitrogen, ammonia & 00608 & $7664-41-7$ & 0.04 & $\mathrm{mg} / \mathrm{L}$ \\
Nitrogen, ammonia + organic nitrogen & 00625 & $17778-88-0$ & .1 & $\mathrm{mg} / \mathrm{L}$ \\
Nitrogen, nitrite & 00613 & $14797-65-0$ & .008 & $\mathrm{mg} / \mathrm{L}$ \\
Nitrogen, nitrite + nitrate & 00631 & -- & .06 & $\mathrm{mg} / \mathrm{L}$ \\
Phosphorus & 00666 & $7723-14-0$ & .04 & $\mathrm{mg} / \mathrm{L}$ \\
Phosphorus, phosphate, ortho & 00671 & $14265-44-2$ & .018 & $\mathrm{mg} / \mathrm{L}$ \\
Phosphorus & 00665 & $7723-14-0$ & .04 & $\mathrm{mg} / \mathrm{L}$ \\
\hline
\end{tabular}

Table 2E. Constituents in surface-water analysis, U.S. Geological Survey National Water-Quality Laboratory Schedule 1817.

[CAS, Chemical Abstracts Service; RL, reporting limit; mg/L, milligrams per liter; --, not applicable]

\begin{tabular}{lllcl}
\hline Constituent & Parameter code & CAS number & RL & Units \\
\hline Nitrogen, ammonia + organic nitrogen & 00623 & $17778-88-0$ & 0.1 & $\mathrm{mg} / \mathrm{L}$ \\
Nitrogen, nitrite + nitrate & 00631 & -- & $.06 \mathrm{mg} / \mathrm{L}$ \\
Phosphorus & 00666 & $7723-14-0$ & $.004 \mathrm{mg} / \mathrm{L}$ \\
\hline
\end{tabular}



